\title{
Seasonal variations in carbon dioxide exchange in an alpine wetland meadow on the Qinghai-Tibetan Plateau
}

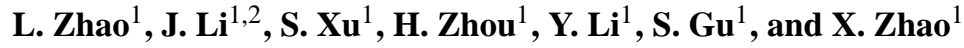 \\ ${ }^{1}$ Northwest Plateau Institute of Biology, Chinese Academy of Sciences, Xining 81001, China \\ ${ }^{2}$ Graduate University of Chinese Academy of Sciences, Chinese Academy of Sciences, Beijing 100049, China
}

Received: 2 June 2009 - Published in Biogeosciences Discuss.: 11 September 2009

Revised: 2 March 2010 - Accepted: 18 March 2010 - Published: 6 April 2010

\begin{abstract}
Alpine wetland meadow could functions as a carbon sink due to it high soil organic content and low decomposition. However, the magnitude and dynamics of carbon stock in alpine wetland ecosystems are not well quantified. Therefore, understanding how environmental variables affect the processes that regulate carbon fluxes in alpine wetland meadow on the Qinghai-Tibetan Plateau is critical. To address this issue, Gross Primary Production (GPP), Ecosystem Respiration $\left(R_{\text {eco }}\right)$, and Net Ecosystem Exchange (NEE) were examined in an alpine wetland meadow using the eddy covariance method from October 2003 to December 2006 at the Haibei Research Station of the Chinese Academy of Sciences. Seasonal patterns of GPP and $R_{\text {eco }}$ were closely associated with leaf area index (LAI). The $R_{\text {eco }}$ showed a positive exponential to soil temperature and relatively low $R_{\text {eco }}$ occurred during the non-growing season after a rain event. This result is inconsistent with the result observed in alpine shrubland meadow. In total, annual GPP were estimated at 575.7, 682.9, and 630.97 $\mathrm{g} \mathrm{C} \mathrm{m}^{-2}$ in 2004, 2005, and 2006, respectively. Meanwhile, the $R_{\text {eco }}$ were equal to 676.8 , 726.4, 808.2 $\mathrm{g} \mathrm{C} \mathrm{m}^{-2}$, and thus the NEE were 101.1, 44.0 and $173.2 \mathrm{~g} \mathrm{C} \mathrm{m}^{-2}$. These results indicated that the alpine wetland meadow was a moderately source of carbon dioxide $\left(\mathrm{CO}_{2}\right)$. The observed carbon dioxide fluxes in the alpine wetland meadow were higher than other alpine meadow such as Kobresia humilis meadow and shrubland meadow.
\end{abstract}

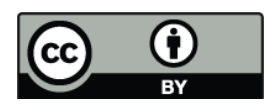

Correspondence to: X. Zhao

(xqzhao@nwipb.ac.cn)

\section{Introduction}

Global wetlands occupy an area of 5.3-6.4 $\mathrm{M} \mathrm{km}^{2}$ on Earth (Matthews and Fung, 1987; Lappalainen, 1996). Northern wetlands play an important role in the global terrestrial carbon cycle. Development of such wetlands has reduced atmospheric $\mathrm{CO}_{2}$ concentrations and affected the global climate system by reducing the greenhouse effect (Moore et al., 1998). It is estimated that northern peatlands cover 34600 $\mathrm{km}^{2}$ of the Earth's surface and represent a soil carbon stock of $455 \mathrm{Pg} \mathrm{C}$ (Gorham, 1991). The deep organic soils stored in wetlands have been accumulating carbon for 4000-5000 years. However, temperature increases due to climate change and drainage of wetlands may provide conditions to reverse this trend, leading to overall carbon loss.

The Qinghai-Tibetan Plateau, with an average altitude of $4000 \mathrm{~m}$ above sea level, is the largest grassland unit on the Eurasian continent, and its lakes and wetlands occupy considerable area (ca. $50000 \mathrm{~km}^{2}$; Zhao et al., 1999). As the most important three grassland types in the unique plateau: alpine meadow, alpine shrubland meadow, and alpine wetland meadow, occupy areas of $0.48 \times 10^{6}, 0.106 \times 10^{6}$ and $0.049 \times 10^{6} \mathrm{~km}^{2}$, respectively (Sun, 1996).

Alpine wetland ecosystems are unique on the QinghaiTibetan Plateau because they are typically underlain by permafrost, maintain a water table near the surface, and have a diverse vegetation composition consisting of both vascular and nonvascular plants (Zhao and Zhou, 1999). Climatic change is expected to have pronounced effects on these landscapes. Future warming is predicted to shorten the frozen period, increase precipitation, enhance evaporation, promote surface drying, increase the length of the growing season, advance active layer deepening, and have a significant impact on photosynthesis, plant respiration, and organic

Published by Copernicus Publications on behalf of the European Geosciences Union. 
Table 1. Average daily values of photosynthetically active radiation (PPFD), air temperature ( $T a$ ), vapor pressure deficit (VPD), soil temperature (Ts: $5 \mathrm{~cm}$ depth), total precipitation (PPT), ecosystem respiration $\left(R_{\mathrm{eco}}\right)$, gross primary production $(\mathrm{GPP})$, and net ecosystem carbon exchange(NEE) for various periods during each year: pre-growing period (1 January to 20 April), Growing season (21 April to 26 October), Senescence (27 October to 31 December), and Annual. Data were from 1 January, 2004 to 31 December, 2006.

\begin{tabular}{lcrrrrrrrr}
\hline Period & Year & $\begin{array}{r}\text { PPFD } \\
\mathrm{molm}^{-2} \mathrm{~d}^{-1}\end{array}$ & $\begin{array}{r}T a \\
{ }^{\circ} \mathrm{C}\end{array}$ & $\begin{array}{r}T s \\
{ }^{\circ} \mathrm{C}\end{array}$ & $\begin{array}{r}\mathrm{VPD} \\
\mathrm{kPa}\end{array}$ & $\begin{array}{r}\mathrm{PPT} \\
\mathrm{mm}\end{array}$ & $\begin{array}{r}\mathrm{NEE} \\
\mathrm{gCm}^{-2}\end{array}$ & $\begin{array}{r}\mathrm{GPP} \\
\mathrm{gCm}^{-2}\end{array}$ & $\begin{array}{r}R_{\text {eco }} \\
\mathrm{gCm}^{-2}\end{array}$ \\
\hline \multirow{2}{*}{ Pre growing } & 2004 & 23.98 & -9.4 & -3.0 & 0.18 & 36.9 & 80.0 & - & 80.0 \\
& 2005 & 22.58 & -8.3 & -2.9 & 0.19 & 32.5 & 62.8 & - & 82.8 \\
& 2006 & 23.53 & -9.2 & -3.0 & 0.18 & 29.2 & 85.8 & - & 85.8 \\
Growing & 2004 & 30.51 & 5.6 & 6.9 & 0.66 & 446.9 & -46.3 & 600.1 & 529.4 \\
& 2005 & 30.26 & 6.4 & 8.1 & 0.71 & 438.5 & -73.0 & 710.3 & 671.9 \\
\multirow{5}{*}{ Senescence } & 2006 & 29.68 & 6.4 & 8.4 & 0.71 & 529.0 & 24.8 & 631.0 & 659.9 \\
& 2004 & 17.88 & -9.8 & -1.1 & 0.17 & 9.8 & 67.4 & - & 67.4 \\
& 2005 & 17.36 & -10.6 & -1.7 & 0.15 & 4.2 & 55.0 & - & 55.0 \\
Annual & 2006 & 17.05 & -9.8 & -1.1 & 0.18 & 4.2 & 63.8 & - & 63.8 \\
& 2004 & 26.32 & -1.5 & 2.34 & 0.43 & 493.5 & 101.1 & 575.7 & 676.8 \\
& 2005 & 25.66 & -1.0 & 2.17 & 0.45 & 475.2 & 44.0 & 682.9 & 726.9 \\
& 2006 & 25.87 & -0.8 & 3.58 & 0.47 & 562.4 & 173.2 & 631.0 & 808.2 \\
\hline
\end{tabular}

decomposition rates on the plateau. Alpine wetland meadow ecosystems store a large amount of soil organic carbon, about $2.5 \%$ of the global soil carbon pool. Moreover, $8 \%$ of the soil organic carbon is stored in plateau wetlands (Wang et al., 2002), due to its low decomposition rate. The unique climate of the region is characterized by long cold winters, a short growing season, and cool summers with relatively high precipitation. In summer, the relatively humid climate supports high productivity and induces inputs of organic carbon to the soil. In winter, the rate of decomposition of organic carbon is low due to the cold environment. Nevertheless, most recent carbon-budget studies of meadow ecosystems have been conducted in alpine $K$. humilis meadow or P. fruticosa shrubland ecosystems (Kato et al., 2006; Zhao et al., 2005a, b, 2006) The results shown that alpine Kobresia humilis meadow or Potentilla fruticosa shrubland ecosystems sequester carbon on the Qinghai-Tibetan Plateau, at least under normal climatic conditions (Zhao et al., 2006, 2007; Kato et al., 2006). What's more, much less attention has been given to $\mathrm{CO}_{2}$ exchange in high-elevation alpine wetland ecosystems (Zhao et al., 2005b). Therefore, a discussion of their carbon cycle is very important to profoundly understanding the plateau, as well as the carbon cycle of other high-altitude grassland ecosystems around the world.

Eddy covariance technology provides a reliable approach to measure the net $\mathrm{CO}_{2}$ exchange of an ecosystem. Using this method, it is possible to interpret whole-system variability based on knowledge of leaf and whole-plant physiology (Amthor et al., 1994; Hollinger et al., 1994). This micrometeorological approach has been widely used in various terrestrial ecosystems (Aubinet et al., 2000; Baldocchi et al., 2001; Yamamoto et al., 2001). The authors used the eddy covariance method and measured the $\mathrm{CO}_{2}$ exchange between the atmosphere and the ecosystem from January 2004 to December 2006 in an alpine wetland meadow on the QinghaiTibetan Plateau. The aims of this study are to (1) fully understand the complex interrelationship between climate and phenology and their effects on $\mathrm{CO}_{2}$ flux; (2) explore the causes of interannual variability of $\mathrm{CO}_{2}$ flux; (3) examine how carbon cycle will change under different climatic conditions.

\section{Materials and methodology}

\subsection{Site description}

The experimental site was located in the vicinity of the Haibei Research Station, Chinese Academy of Sciences, in Qinghai province, China $\left(37^{\circ} 35^{\prime} \mathrm{N}, 101^{\circ} 20^{\prime} \mathrm{E}\right.$, $3250 \mathrm{~m}$ a.s.1.), and the measurement were conducted from October 2003 to December 2006. The eddy covariance (EC) method was used to examine carbon dynamics and variability. This wetland is characterized by non-patterned, hummock-hollow terrain, with hummocks representing $40 \%$, hollows $55 \%$, and other features $5 \%$ of the landscape, it covers about $6 \mathrm{~km}$. The catchment is flooded at an average water depth of $30 \mathrm{~cm}$ during the growing season. Wetland vegetation is dominated by four species (K. tibetica, Carex pamirensis, Hippuris vulgaris, Blysmus sinocompressus), and distributed in different zones along a gradient of water depth reaching maximum values of $25-30 \mathrm{~cm}$ (Zhao et al., $2005 b)$. The soil is a silty clay loam of Mat-Cryic Cambisols with heavy clay starting at depths between 0.1 and $1.0 \mathrm{~m}$. The local climate is characterized by strong solar radiation with 
Table 2. Published study sites characteristics, environmental variables and carbon fluxes.

\begin{tabular}{|c|c|c|c|c|c|c|c|c|c|c|}
\hline Site & Latitude & Longitude & $\begin{array}{r}\text { Elevation } \\
(\mathrm{m})\end{array}$ & LAI $m^{2} m^{-2}$ & Period & $\begin{array}{l}\mathrm{Ta} \\
{ }^{\circ} \mathrm{C}\end{array}$ & $\begin{array}{r}\text { GPP } \\
\mathrm{g} \mathrm{C} \mathrm{m}^{-2} \mathrm{y}^{-1}\end{array}$ & $\begin{array}{r}\text { NEE } \\
\mathrm{g} \mathrm{C} \mathrm{m}^{-2} \mathrm{y}^{-1}\end{array}$ & $\begin{array}{r}R_{\mathrm{eco}} \\
\mathrm{gC} \mathrm{m}^{-2} \mathrm{y}^{-1}\end{array}$ & Reference \\
\hline $\begin{array}{l}\text { Alpine wetland } \\
\text { meadow }\end{array}$ & $37^{\circ} 35^{\prime}$ & $101^{\circ} 20^{\prime}$ & 3250 & 3.9 & $\begin{array}{l}2004 \\
2005 \\
2006\end{array}$ & $\begin{array}{l}-1.5 \\
-1.0 \\
-0.8\end{array}$ & $\begin{array}{l}575.7 \\
682.9 \\
631.0\end{array}$ & $\begin{array}{r}101.1 \\
44.0 \\
173.2\end{array}$ & $\begin{array}{l}676.8 \\
726.4 \\
808.2\end{array}$ & This Study \\
\hline $\begin{array}{l}\text { Alpine Kobresia } \\
\text { humilis meadow }\end{array}$ & $37^{\circ} 36^{\prime}$ & $101^{\circ} 20^{\prime}$ & 3250 & 3.8 & $\begin{array}{l}2002 \\
2003 \\
2004\end{array}$ & $\begin{array}{l}-0.7 \\
-0.9 \\
-1.5\end{array}$ & $\begin{array}{l}575.1 \\
647.3 \\
681.1\end{array}$ & $\begin{array}{r}-78.5 \\
-91.7 \\
-192.5\end{array}$ & $\begin{array}{l}496.6 \\
555.6 \\
488.5\end{array}$ & Kato et al. (2006) \\
\hline $\begin{array}{l}\text { Alpine shrubland } \\
\text { meadow }\end{array}$ & $37^{\circ} 36^{\prime}$ & $101^{\circ} 18^{\prime}$ & 3250 & 2.2 & $\begin{array}{l}2003 \\
2004\end{array}$ & $\begin{array}{r}-1.23 \\
-1.9\end{array}$ & $\begin{array}{l}544.0 \\
559.4\end{array}$ & $\begin{array}{l}-58.82 \\
-75.46\end{array}$ & $\begin{array}{l}485.2 \\
483.9\end{array}$ & Zhao et al. (2006) \\
\hline $\begin{array}{l}\text { Mediterranean } \\
\text { annual grassland }\end{array}$ & $38^{\circ} 24^{\prime}$ & $120^{\circ} 57^{\prime}$ & 129 & 2.5 & $\begin{array}{l}2000-2001 \\
2001-2002\end{array}$ & 16.2 & $\begin{array}{l}867 \\
729\end{array}$ & $\begin{array}{r}-131 \\
29\end{array}$ & $\begin{array}{l}735 \\
758\end{array}$ & Xu and Baldocchi (2004) \\
\hline Sedge-dominated fen & $74^{\circ} 28^{\prime} \mathrm{N}$ & $20^{\circ} 34^{\prime} \mathrm{W}$ & 1500 & 1.2 & 1996 & -19.5 & - & -64.4 & - & Soegaard and Nordstroem (1999) \\
\hline $\begin{array}{l}\text { Boreal minerotrophic } \\
\text { patterned fen }\end{array}$ & $53^{\circ} 57^{\prime} \mathrm{N}$ & $105^{\circ} 57^{\prime} \mathrm{W}$ & & 1.3 & $\begin{array}{r}\text { Mid-day to early } \\
\text { October } 1994\end{array}$ & $9.2-28.2$ & - & -88 & - & Suyker et al. (1997) \\
\hline Tussock tundra & $68^{\circ} 38^{\prime}$ & $149^{\circ} 35^{\prime}$ & 732 & - & 1990 & - & - & 156 & - & Oechel et al. (1993) \\
\hline Wet sedge tundra & $70^{\circ} 22^{\prime}$ & $148^{\circ} 45^{\prime}$ & 3 & - & 1990 & - & - & 34 & - & Oechel et al. (1993) \\
\hline Flakaliden & 64.11 & 19.46 & 226 & 3.4 & 1997 & 3.0 & 699 & -193 & 526 & Law et al. (2002) \\
\hline Glacier lake & 41.37 & -106.24 & 3186 & 2.5 & 1996 & -0.7 & 407 & 195 & 212 & Zeller and Nikolov (2000) \\
\hline Metolius-intemediate & 44.45 & -121.56 & 1310 & 2.96 & $1996-1997$ & 8.7 & 454 & 27 & 481 & Baldocchi et al. (2000) \\
\hline
\end{tabular}

long cold winters and short cool summers. The annual mean air temperature recorded at the station is $-1.7^{\circ} \mathrm{C}$; the coldest month is January (with an average value of $-15^{\circ} \mathrm{C}$ ), and the warmest month is July (mean $10^{\circ} \mathrm{C}$ ). The annual mean precipitation is about $570 \mathrm{~mm}$; more than $80 \%$ of the precipitation concentrated in the growing season from May to September. The grassland turns green at the end of April or the beginning of May, depending on the year. The study site is grazed by yaks and Tibetan sheep from June to September, with a low stocking rate of about one animal per hectare.

\subsection{Eddy covariance, meteorological, and soil measurements}

$\mathrm{CO}_{2}$ and $\mathrm{H}_{2} \mathrm{O}$ fluxes were measured at a height of $2.2 \mathrm{~m}$ in the center of an open area of at least $1 \mathrm{~km}$ in all directions using the open-path eddy covariance method from 1 October 2003 to 31 December 31 2006. Further details are described in Zhao et al. (2005a). The eddy covariance sensor array included a three-dimensional sonic anemometer (CSAT-3, Campbell Scientific Inc., Logan, Utah, United States) and an open-path infrared gas analyzer (CS7500, Campbell Scientific Inc.). Wind speed, sonic virtual temperature, and $\mathrm{CO}_{2}$ and $\mathrm{H}_{2} \mathrm{O}$ concentrations were sampled at a rate of $10 \mathrm{~Hz}$. Their mean, variance, and covariance values were calculated and logged every 30 min with a CR5000 data logger (Campbell Scientific Inc., Logan, Utah, United States). The collected data were adjusted using the WPL (Webb, Pearman, and Leuning) density adjustment (Webb et al., 1980). In this study, three common flux data corrections (coordinate rotation, trend removal, and water vapor correlation) were not performed. However, the effect of lacking of these corrections on the calculated flux was examined for 10 days in July 2004 using flux data sampled at the frequency of $10 \mathrm{~Hz}$, and the implicit estimation error in the flux data was evalu- ated by comparing corrected and uncorrected fluxes in $\mathrm{CO}_{2}$ flux calculations. The regression line slopes (slope $=0.99$, $\left.r^{2}=0.53\right)$, showed small differences $(<1 \%)$ between corrected and uncorrected fluxes. This result indicated that the small negative bias resulting from the omission of these corrections can be negligible in the study. The $\mathrm{CO}_{2} / \mathrm{H}_{2} \mathrm{O}$ analyzer system was calibrated on 10 May 2004, 15 May 2005 and 11 May 2006, respectively. Zero points were established using $99.999 \% \mathrm{~N}_{2}$ gas, the $\mathrm{CO}_{2}$ span was calibrated using a standard gas bottle of $\mathrm{CO}_{2}$, and the water vapor measurement was calibrated using a dewpoint generator (model Li610; LiCor, Lincoln, NE). The calibration showed that the cumulative deviations for zero drift and span change for both $\mathrm{CO}_{2}$ and water vapor channels over a period of one full year were less than 2 and $0.5 \%$, respectively. Thus, shift of zero and span over a month period considered to be insignificant.

Mean air temperature $(T a)$, humidity, wind speed, Photosynthetic Photon Flux Density (PPFD), net radiation $\left(R_{\mathrm{n}}\right)$, soil heat flux $(G)$, and soil temperature $(T s)$ were also measured. Soil moisture was determined using time-domain reflectometry (TDR). These data were sampled and logged every $30 \mathrm{~min}$ using a digital micrologger (CR23X, Campbell Scientific, Inc.). It equipped with an analog multiplexer (AM25T).

\subsection{Green Leaf Area Index (LAI) and biomass}

Green and total LAI and biomass were measured by harvesting the vegetation approximately every two weeks during the growing season.

\subsection{Eddy covariance flux data processing and gap filling}

NEE (net ecosystem production as $\mathrm{CO}_{2}$ uptake, i.e., NEE) was calculated from the sum of the eddy covariance flux, $F_{\mathrm{c}}$ 
and the storage term $\left(F_{\mathrm{s}}\right)$. The $F_{\mathrm{c}}$ is sum of EC-measured flux and $F_{\mathrm{S}}$ is the flux associated with the change in storage in $\mathrm{CO}_{2}$ in the layer below the level of $\mathrm{CO}_{2}$ flux measurement and the values of $F_{\mathrm{s}}$ were obtained by integrating the change in $\mathrm{CO}_{2}$ concentration through the air layer up to the heights of the eddy covariance sensors (Suyker and Verma, 2001).For in the study site the flux measurement system was only $2.2 \mathrm{~m}$ , the storage term $F_{\mathrm{s}}$ was smaller more than $F_{\mathrm{c}}$, and the daily calculate values tend to zero, so the $F_{\mathrm{s}}$ was neglected in the calculated of NEE.

GPP was calculated as the sum of NEE and $R_{\text {eco }}$, as follows:

$\mathrm{GPP}=-\mathrm{NEE}+R_{\text {eco }}$

All flux and meteorological data were applied data quality criteria after data collection. Overall flux recovery was $82 \%$, which is typical of flux recovery rates for most Fluxnet sites reported by Wilson et al. (2002). Ground heat flux $(G)$ was calculated as the average of the three soil heat flux plates, and was corrected for heat storage above the plates. Rate of $\mathrm{H}$ and LE were stored in the air column below EC sensors. An examination of the energy budget closure indicated: $(H+$ $L E)=0.74 \cdot\left(R_{\mathrm{n}}+G\right) 22.45, r^{2}=0.94$, where $H$ and $L E$ are the flux of sensible heat and latent heat, respectively. The slope fell in the median region of reported energy closures, which range from 0.55 to 0.99 (Wilson et al., 2002). The lack of energy balance closure has also been reported (Aubinet et al., 2000; Gu et al., 1999), and energy balance closure has accepted as an new test of eddy covariance (Mahrt, 1998).

When daytime half-hourly values were missed, the net flux density of $\mathrm{CO}_{2}\left(F_{\mathrm{c}}\right)$ flux was estimated as a hyperbolic function of incident PPFD (adjacent days were included to establish the relationship, as shown in Eq. (2). Missing $R_{\text {eco }}$ values were extrapolated by exponential regression Eq. (3) between measured nighttime $R_{\text {eco }}$ under well-mixed conditions $\left(u^{*}>0.1 \mathrm{~ms}^{-1}\right.$, Aubinet et al., 2000; Lloyd, 2006), with soil temperature at $-5 \mathrm{~cm}$ depth. Nighttime eddy covariance flux data under low-turbulence conditions, that is, below the $u^{*}$ threshold (Aubinet et al., 2000; $0.1 \mathrm{~ms}^{-1}$ in this study), were also corrected by the regression fuction (Eq. 3). Daytime estimates of ecosystem respiration $\left(R_{\text {eco }}\right)$ were obtained from the nighttime $F_{\mathrm{c}}$-temperature relationship (Eq. 3) (Lloyd and Taylor, 1994):

$F_{\mathrm{c}}=\frac{F_{\max } \cdot \alpha \cdot Q_{\mathrm{P}}}{F_{\max }+\alpha \cdot Q_{\mathrm{P}}}+R_{\mathrm{eco}}$

where $Q_{p}\left(\mu \mathrm{mol} \mathrm{m} \mathrm{m}^{-2} \mathrm{~s}^{-1}\right)$ is incident photosynthetically active radiation, $F_{\max }\left(\mu \mathrm{mol} \mathrm{m}{ }^{-2} \mathrm{~s}^{-1}\right)$ the maximum $\mathrm{CO}_{2}$ flux at infinite light, and $\alpha$ the apparent quantum yield. $R_{\text {eco }}$ can be calculated as:

$R_{\mathrm{eco}}=R_{\mathrm{e}, T_{\mathrm{ref}}} \exp \left[\left(E_{\mathrm{a}} / R\right)\left(\frac{1}{T_{\mathrm{ref}}}-\frac{1}{T s}\right)\right]$,

where $R_{\text {eco }}$ is the nighttime ecosystem respiration rate $\left(\mu \mathrm{mol} \mathrm{CO}_{2} \mathrm{~m}^{-2} \mathrm{~s}^{-1}\right), R_{\mathrm{e}, T_{\text {ref }}}$ is the ecosystem respiration rate $\left(\mu \mathrm{mol} \mathrm{CO} \mathrm{CO}_{2} \mathrm{~m}^{-2} \mathrm{~s}^{-1}\right)$ at the reference temperature $T_{\text {ref }}$ $(\mathrm{K})$, and $E_{\mathrm{a}}$ is the activation energy $\left(\mathrm{J} \mathrm{mol}^{-1}\right)$. These latter two parameters are site-specific. $R$ is a gas constant $\left(8.134 \mathrm{~J} \mathrm{~K}^{-1} \mathrm{~mol}^{-1}\right)$, and $T s$ is the soil temperature at a depth of $5 \mathrm{~cm} . R_{\mathrm{e}, T_{\text {ref }}}$ was set to $R_{10}$, the respiration rate at $T_{\text {ref }}$ of $283.16 \mathrm{~K}\left(10^{\circ} \mathrm{C}\right)$, and was evaluated every month during the study period. $E_{\mathrm{a}}$ was evaluated using a regression of all $R_{\mathrm{eco}}$ data in reference year against $T s$ as a constant value throughout each year (for 2004, 2005, and 2006, the values were $50093.43,61084.73$, and $44743.55 \mathrm{Jmol}^{-1}$ respectively).

The monthly and annual average values $( \pm \mathrm{SD})$ of GPP, NEE and $R_{\text {eco }}$ are listed in the Table 3.

\subsection{Data analysis}

Regression analyses were preformed to investigate the relationship of GPP, NEE, or $R_{\text {eco }}$ with concurrent changes in environmental variables ( $T a, T s$, PPFD) using the monthly and annual data using SAS V8 software, as well as the stepwise multi-linear analysis of those variable. The statistical information for the relationship between GPP, NEE, or $R_{\text {eco }}$ and $T a, T s$, PPFD was listed in Table 4 and Table 5, respectively. The multiple linear analyses at annual step were listed in Table 6.

\section{Results}

\subsection{Information on weather conditions, biomass, and leaf area}

Figure 1 shows daily PPFD, average air temperatures at a height of $2.2 \mathrm{~m}$, average soil temperatures at depths of $3 \mathrm{~cm}$, $40 \mathrm{~cm}$, daytime average Vapor Pressure Deficits (VPD) at a height of $2.2 \mathrm{~m}$, and daily total precipitation. The daily average temperatures ranged from -23.6 to $14.3^{\circ} \mathrm{C}$ (air temperature), -6.2 to $12.0^{\circ} \mathrm{C}$ (soil temperature at $5 \mathrm{~cm}$ depth), and 0 to $8.5^{\circ} \mathrm{C}$ (soil temperature at $40 \mathrm{~cm}$ depth). The maximum temperatures recorded from the late of July to the early of August. PPFD reached its annual maximum in the beginning of July and then decreased gradually. There were no significant differences in PPFD or VPD among the years 2004, 2005, and 2006 (years differences did not exceed 5\%, PPFD: $F_{(2,1071)}=1.07, P>0.05$; VPD: $\left.F_{(2,1071)}=1.26, P>0.05\right)$, as shown in Table 1. It was slightly cooler in 2004 than 2005 and 2006. Precipitation concentrated in the period from May to August (Fig. 1e). Total annual precipitation in 2004 was similar to 2005, but slightly less than 2006 (Table 1).

Above-ground biomass increased from mid-April (DOY100) each year and reached maximum of 305.3$335.6 \mathrm{~g} \mathrm{~m}^{-2}$ during late August. Maximum Leaf Area Index (LAI) followed the similar trend of green biomass and reached $3.9 \mathrm{~m}^{2} \mathrm{~m}^{-2}$ in 2005 . 
Table 3. The monthly and annual average values $( \pm \mathrm{SD})$ of NEE, GPP, and $R_{\mathrm{eco}}\left(\mathrm{g} \mathrm{C} \mathrm{m}^{-2} \mathrm{~d}^{-1}\right)$. Data are from January 2004 to December 2006, and the symbol (-) indicate the value of GPP was zero during the no growing season.

\begin{tabular}{cccccccccccccc}
\hline & January & February & March & April & May & June & July & August & September & October & November & December & Annual \\
\hline$N E E$ & $0.49 \pm 0.18$ & $0.61 \pm 0.30$ & $0.72 \pm 0.35$ & $1.32 \pm 0.59$ & $1.17 \pm 0.49$ & $0.22 \pm 0.77$ & $-2.31 \pm 0.84$ & $-1.46 \pm 0.85$ & $0.05 \pm 0.76$ & $0.90 \pm 0.62$ & $1.02 \pm 0.27$ & $0.77 \pm 0.32$ & $0.29 \pm 1.20$ \\
GPP & - & - & - & $0.10 \pm 0.38$ & $0.95 \pm 0.51$ & $3.43 \pm 1.03$ & $5.55 \pm 1.04$ & $5.76 \pm 0.94$ & $3.39 \pm 1.00$ & $1.33 \pm 0.84$ & - & - & $1.72 \pm 2.25$ \\
$R_{\text {eco }}$ & $0.49 \pm 0.18$ & $0.61 \pm 0.30$ & $0.72 \pm 0.35$ & $1.42 \pm 0.60$ & $2.12 \pm 0.48$ & $3.66 \pm 0.81$ & $3.29 \pm 0.54$ & $4.31 \pm 0.92$ & $3.44 \pm 0.58$ & $2.29 \pm 0.97$ & $1.02 \pm 0.27$ & $0.77 \pm 0.32$ & $2.02 \pm 1.43$ \\
\hline
\end{tabular}

\subsection{Response of $R_{\text {eco }}$ to temperature}

Figure 2 shows the specific response of ecosystem respiration rate to soil temperature during the growing period at monthly step for 2004, 2005, and 2006. The exponential function given in Eq. (3) was used to describe the relationship between $R_{\text {eco }}$ and soil temperature at 5-cm depth. From Eq. (3), $R_{10}$ was estimated to be $2.3-5.5$ during the growing period. Meanwhile, high $R_{10}$ values were observed in the initial stage of growth (May and June, Fig. 2), whereas low $R_{10}$ values occurred mostly in the wet season when grass grown vigorously (July and August, Fig. 2). Figure 3 shows the relationship between $R_{\text {eco }}$ and soil temperature (at $5 \mathrm{~cm}$ ) in the non-growing season. $R_{10}$ values were estimated to be 2.7, 2.7, and 2.6 in 2004, 2005, and 2006 respectively, it was clearly lower than the $R_{10}$ values evaluated during the growing season (Fig. 2), consisted with the result of Zhao et al. (2006). The annual average $R_{10}$ were $3.05,2.98$, and $3.24 \mu \mathrm{mol} \mathrm{Cm}^{-2} \mathrm{~s}^{-1}$ for 2004,2005 , and 2006 , whereas the annual active energy $\left(E_{\mathrm{a}}\right)$ values were $50093.43,61084.73$, and $44743.5 \mathrm{~J} \mathrm{~mol}^{-1}$ respectively. Thus, the temperature dependence of $R_{10}$ was higher in 2004 and 2006 than in 2005.

\subsection{GPP in relation to PPFD}

Figures 4 and 5 show the relationship between GPP and PPFD from May to September. In the morning the values of GPP responded exponentially to PPFD during July to September (Fig. 4). However, the dependence of these fluxes on PPFD changed with the seasons. The values of GPP increased from May to August under the constant PPFD condition. In September, although the LAI increased, the dependence of GPP on PPFD did not change greatly.

Based on statistical analysis using Eq. (2), GPP SAT in May to September ranged from 1.67 to $16.21 \mu \mathrm{mol} \mathrm{m}^{-2} \mathrm{~s}^{-1}$, it gradually increased during May to August and then decreased in September. And $\alpha$ varied 30-fold across the growing stage, from a minimum of 0.003 in early season to 0.103 in June. The quantum yield was not within the range of published data for $\mathrm{C}_{3}$ grasses (Ruimy et al., 1995; Flanagan et al., 2002; $\mathrm{Xu}$ and Baldocchi, 2004), and was higher than the values from other eddy covariance studies in temperate $\mathrm{C}_{3}$ grassland (Flanagan et al., 2002). The quantum yield values of the alpine wetland were higher than the values of the alpine shrubland meadow, which is located in the vicinity of

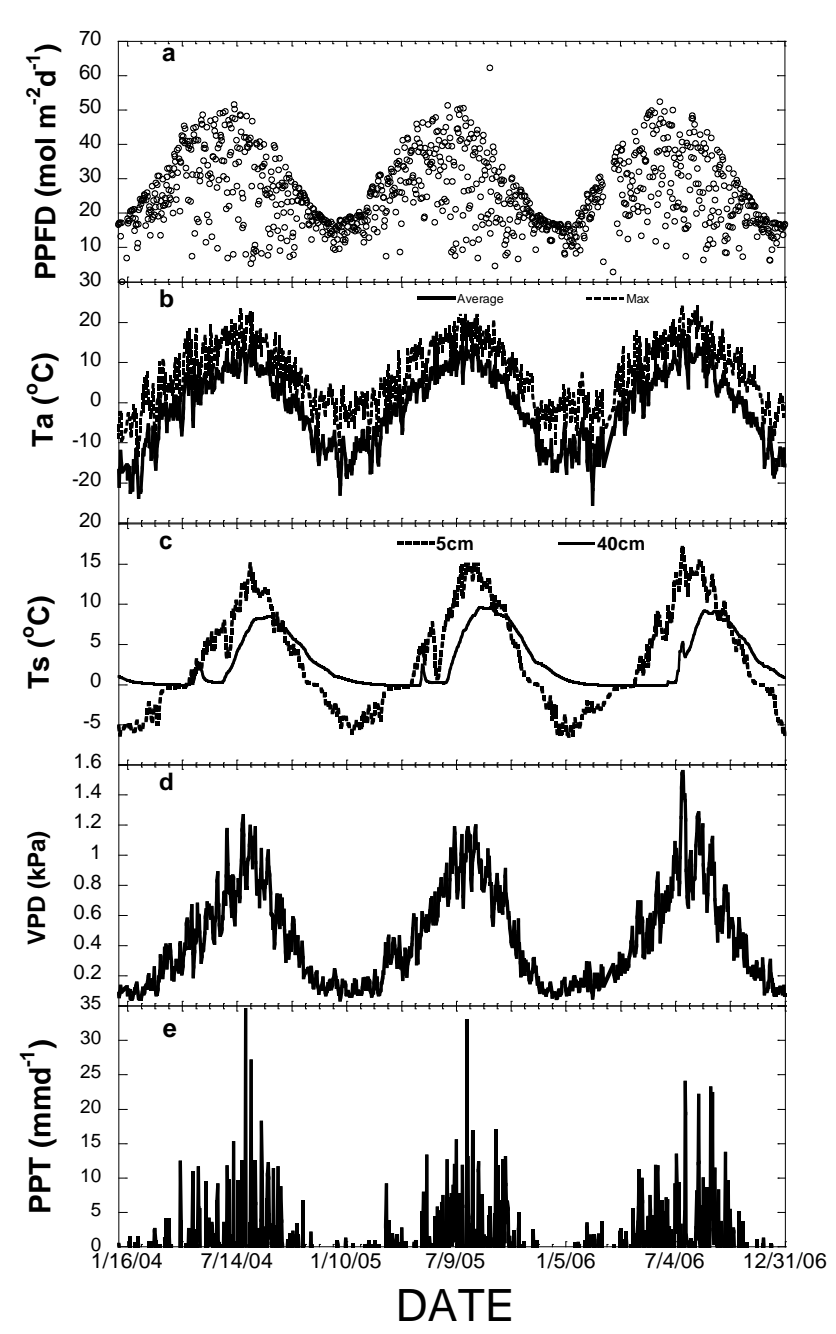

Fig. 1. Seasonal variability of (a) photosynthetically active radiation (PPFD), (b) average daily air temperature $(T a)$, (c) soil temperature at the depth of 5 and $40 \mathrm{~cm}(T s)$, (d) vapor pressure deficit (VPD), and (e) daily total precipitation (PPT).The lines are plotted from 1 January.

the study site (0.0056 and 0.0082 for July and August respectively) (Zhao et al., 2006). However, the photosynthetic capacity of the alpine wetland meadow was smaller than the alpine shrubland meadow (17.93 and $20.54 \mu \mathrm{mol} \mathrm{m}^{-2} \mathrm{~s}^{-1}$ for July and August, respectively), probably due to the shrubland 
Table 4. Characteristics of linear regression analysis $[y=a x+b]$ of daily mean ecosystem respiration $\left(R_{\mathrm{eco}}\right.$, in $\left.\mu \mathrm{mol} \mathrm{m} \mathrm{m}^{-2} \mathrm{~d}^{-1}\right)$ and gross primary productivity (GPP, in $\mu$ mol m${ }^{-2} \mathrm{~d}^{-1}$ ) vs. monthly mean air temperature $\left(\mathrm{Ta}\right.$, in $\left.{ }^{\circ} \mathrm{C}\right)$, and monthly mean soil temperature at the depth of $5 \mathrm{~cm}\left(T s\right.$, in $\left.{ }^{\circ} \mathrm{C}\right)$ for individual month and annual clusters; data are from January 2004 to December 2006.

\begin{tabular}{lrrrrrrrrrrrrrr}
\hline & Jan & Feb & Mar & Apr & May & Jun & Jul & Aug & Sep & Oct & Nov & Dec & Annual \\
\hline GPP vs. $T s$ & & & & & & & & & & & & & \\
$r$ & - & - & - & 0.181 & 0.109 & 0.493 & 0.382 & 0.559 & $\mathbf{0 . 7 4 2}$ & $\mathbf{0 . 7 8 5}$ & - & - & $\mathbf{0 . 9 3 9}$ \\
$a$ & - & - & - & 0.161 & 0.032 & 2.025 & 0.150 & 0.369 & 0.450 & 0.409 & - & - & 0.333 \\
$b$ & - & - & - & 0.121 & 0.835 & 0.228 & 3.784 & 0.942 & -0.840 & -0.427 & - & - & 0.741 \\
GPP vs. Ta & & & & & & & & & & & \\
$r$ & - & - & - & 0.010 & -0.059 & 0.589 & 0.409 & 0.525 & 0.521 & 0.644 & - & - & $\mathbf{0 . 7 9 3}$ \\
$a$ & - & - & - & 0.001 & -0.001 & 0.334 & 0.156 & 0.220 & 0.223 & 0.251 & - & - & 0.194 \\
$b$ & - & - & - & 0.098 & 0.994 & 0.912 & 3.929 & 3.564 & 0.278 & 1.483 & - & - & 1.976 \\
$R_{\text {eco }}$ vs. Ts & & & & & & & & & & & \\
$r$ & 0.077 & 0.447 & 0.057 & 0.658 & 0.419 & $\mathbf{0 . 8 2 9}$ & $\mathbf{0 . 7 8 4}$ & $\mathbf{0 . 7 1 4}$ & 0.642 & 0.673 & 0.573 & 0.474 & $\mathbf{0 . 9 0 7}$ \\
$a$ & 0.018 & 0.137 & 0.013 & 0.946 & 0.119 & 0.302 & 0.158 & 0.460 & 0.227 & 0.399 & 0.328 & 0.095 & 0.211 \\
$b$ & 0.613 & 1.124 & 0.718 & 1.552 & 1.684 & 1.802 & 1.416 & -1.713 & 1.303 & 0.575 & 0.974 & 1.071 & 1.407 \\
\hline
\end{tabular}

The bold number indicated those are statistically significant $(P<0.05)$ and $r$ is the correlation coefficient. Symbol $(-)$ stand for the value of GPP was zero during the non-growing season.
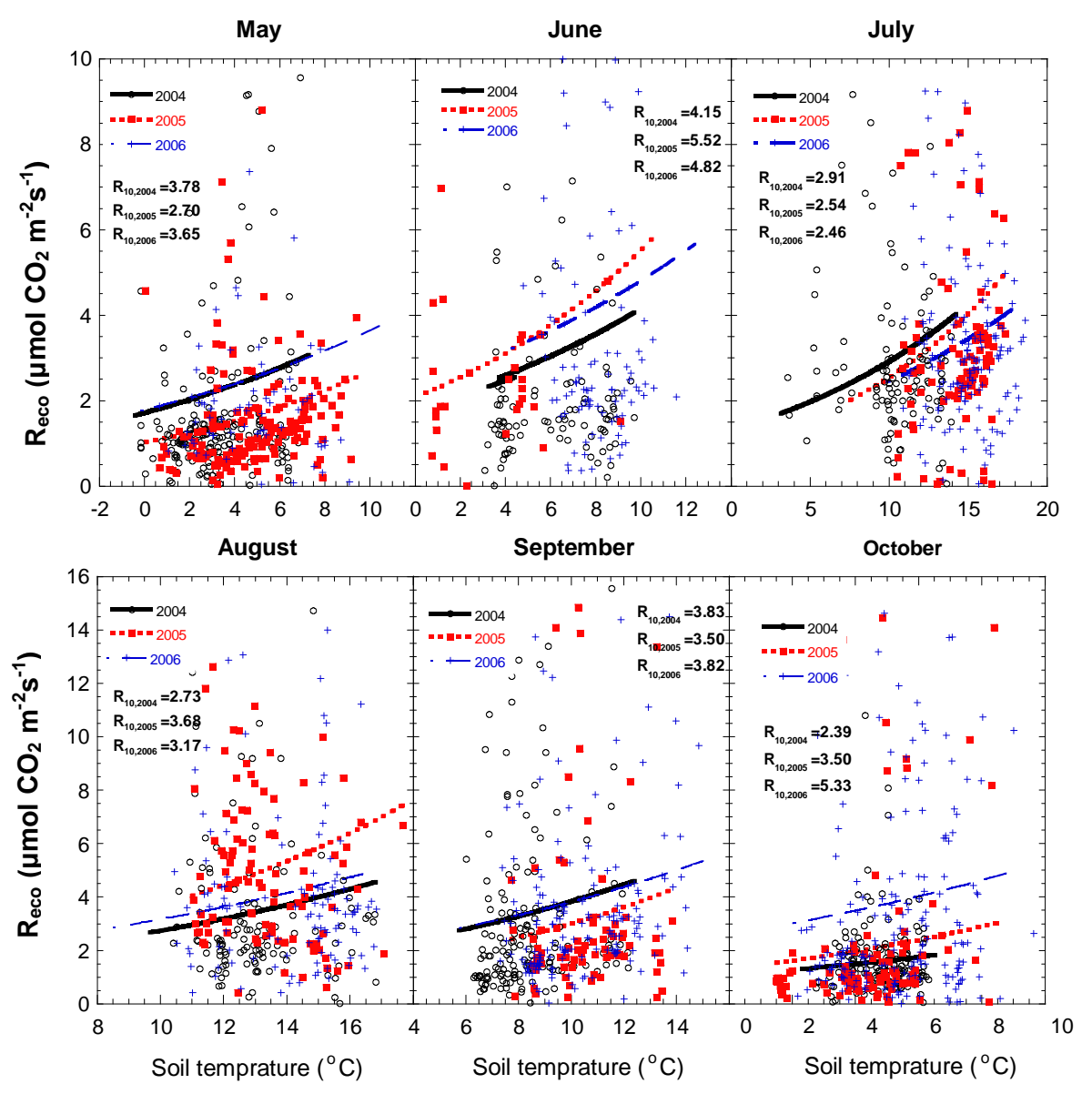

Fig. 2. Response of ecosystem respiration $\left(R_{\mathrm{eco}}\right)$ to change in soil temperature at the depth of $5 \mathrm{~cm}$ during growing season. Data were half-hourly under high turbulence conditions $\left(u^{*}>0.1 \mathrm{~m} \mathrm{~s}^{-1}\right)$ from 2004 to 2006. 
Table 5. Characteristics of linear regression analysis $[y=a x+b]$ of daily net $\mathrm{CO}_{2}$ ecosystem exchange $\left(\mathrm{NEE}\right.$, in $\left.\mu \mathrm{mol} \mathrm{m}{ }^{-2} \mathrm{~d}^{-1}\right) \mathrm{vs}$. monthly mean air temperature $\left(\mathrm{Ta}\right.$, in $\left.{ }^{\circ} \mathrm{C}\right)$, and monthly mean soil temperature at the depth of $5 \mathrm{~cm}\left(\mathrm{Ts}\right.$, in $\left.{ }^{\circ} \mathrm{C}\right)$ for different growth stage; data are from January 2004 to December 2006.

\begin{tabular}{lrrrrrrrr}
\hline & \multicolumn{4}{c}{ NEE vs. Ta } & \multicolumn{4}{c}{ NEE vs. $T s$} \\
Seasonal periods & $r$ & $a$ & $b$ & $P$ & $r$ & $a$ & $b$ & $P$ \\
\hline January-April & 0.551 & 0.039 & 1.112 & $<0.001$ & 0.600 & 0.137 & 1.171 & $<0.001$ \\
May-September & -0.642 & -0.263 & 1.483 & $<0.001$ & -0.670 & -0.243 & 1.684 & $<0.001$ \\
October-December & 0.206 & 0.015 & 1.026 & $<0.001$ & 0.215 & 0.028 & 0.902 & $<0.001$ \\
\hline
\end{tabular}

Table 6. The multi-factor regression analysis of $\mathrm{CO}_{2}$ flux (GPP, NEE, $R_{\mathrm{eco}}$ ) vs. $T a, T s$, PPFD, VPD, the data is on the annual base.

\begin{tabular}{lrrrrrrr}
\hline & $T a$ & $T s$ & VPD & PPFD & intercept & $R^{2}$ & $P$ \\
\hline GPP & -0.113 & 0.212 & 5.344 & 0.002 & -2.411 & 0.871 & $<0.001$ \\
NEE & 0.119 & -0.050 & -4.571 & -0.002 & 3.474 & 0.522 & $<0.001$ \\
$R_{\text {eco }}$ & 0.013 & 0.170 & 0.530 & 0.0004 & 1.312 & 0.828 & $<0.001$ \\
\hline
\end{tabular}

ecosystem has larger canopy size, more vascular plants, and the presence of enough moisture.

Before 13:00 (Beijing Standard Time, BST) at the study site, light response increased with PPFD values until the PPFD reached $830 \mu \mathrm{mol} \mathrm{m}{ }^{-2} \mathrm{~s}^{-1}$ (Fig. 4), and then declined. These results indicated the light-use efficiency decreased while PPFD rose to a significant extent. In the afternoon, GPP responded linearly to PPFD (GPP $=b+a \times \mathrm{PPFD})$ during growing-season, with small $a$ (Fig. 5).

\subsection{GPP in relation to LAI, and depth of water table (DWT)}

The maximum value of GPP occurred during the period of greatest LAI in all years, and GPP decreased with LAI. Figure 6 illustrates the effect of LAI on GPP in 2005. It shows a logistic trend $\left(r^{2}=0.69, P<0.0001\right)$. The "S" shape curve shows that the variation of GPP following the change of LAI in the growing season: the GPP slowly accumulated as LAI in the range of $0-1.2 \mathrm{~m}^{2} \mathrm{~m}^{-2}$ and then rapidly increased with increasing LAI from 1.2 to $2.9 \mathrm{~m}^{2} \mathrm{~m}^{-2}$. Daily total GPP switched to stabilize with the further increase in LAI above $2.9 \mathrm{~m}^{2} \mathrm{~m}^{-2}$.

$R_{\text {eco }}$ from peat soils is commonly dependent on $D_{\mathrm{WT}}$ since aerobic microbial activity increases with decreasing $D_{\mathrm{WT}}$ (Andreis, 1976; Stephens et al., 1984; Hodge, 2002; Lloyd 2006). Unexpectedly, the authors did not observe decreases of nighttime $R_{\text {eco }}$ with increasing $D_{\mathrm{WT}}$. Linear relationships between $R_{10}$ and $D_{\mathrm{WT}}$ were insignificant $\left(r^{2}=0.02, n=38\right.$, $P>0.05)$ for alpine wetland meadow.

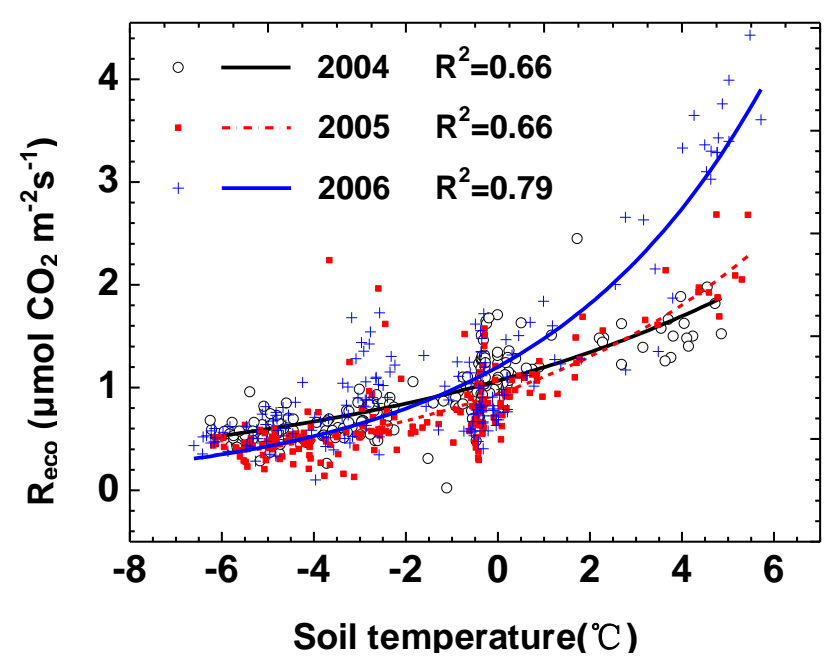

Fig. 3. Response of ecosystem respiration $\left(R_{\mathrm{eco}}\right)$ to variety of soil temperature at the depth of $5 \mathrm{~cm}$ during non-growing season. Data were half-hourly under high turbulence conditions $\left(u^{*}>0.1 \mathrm{~ms}^{-1}\right)$ from 2004 to 2006.

\subsection{Influence of rain events on non growing $R_{\text {eco }}$}

Small pulses of $R_{\text {eco }}$ were observed immediately after individual rain events during the non-growing period. Data from 5 October 2004 to 1 February 2005, are presented in Fig. 7. The rain event I occurred on 9 October 2004, with total precipitation of only $1.7 \mathrm{~mm} /$ day (Fig. 7). On October $11, R_{\text {eco }}$ suddenly decreased to $4.74 \mathrm{~g} \mathrm{C} \mathrm{m}^{-2}$ per day from the background level of $8.70 \mathrm{~g} \mathrm{C} \mathrm{m}^{-2}$ per day observed a few days ago. Then after two days, $R_{\text {eco }}$ increased to $7.25 \mathrm{~g} \mathrm{C} \mathrm{m}^{-2}$ per day, as observed on 13 October. After the 


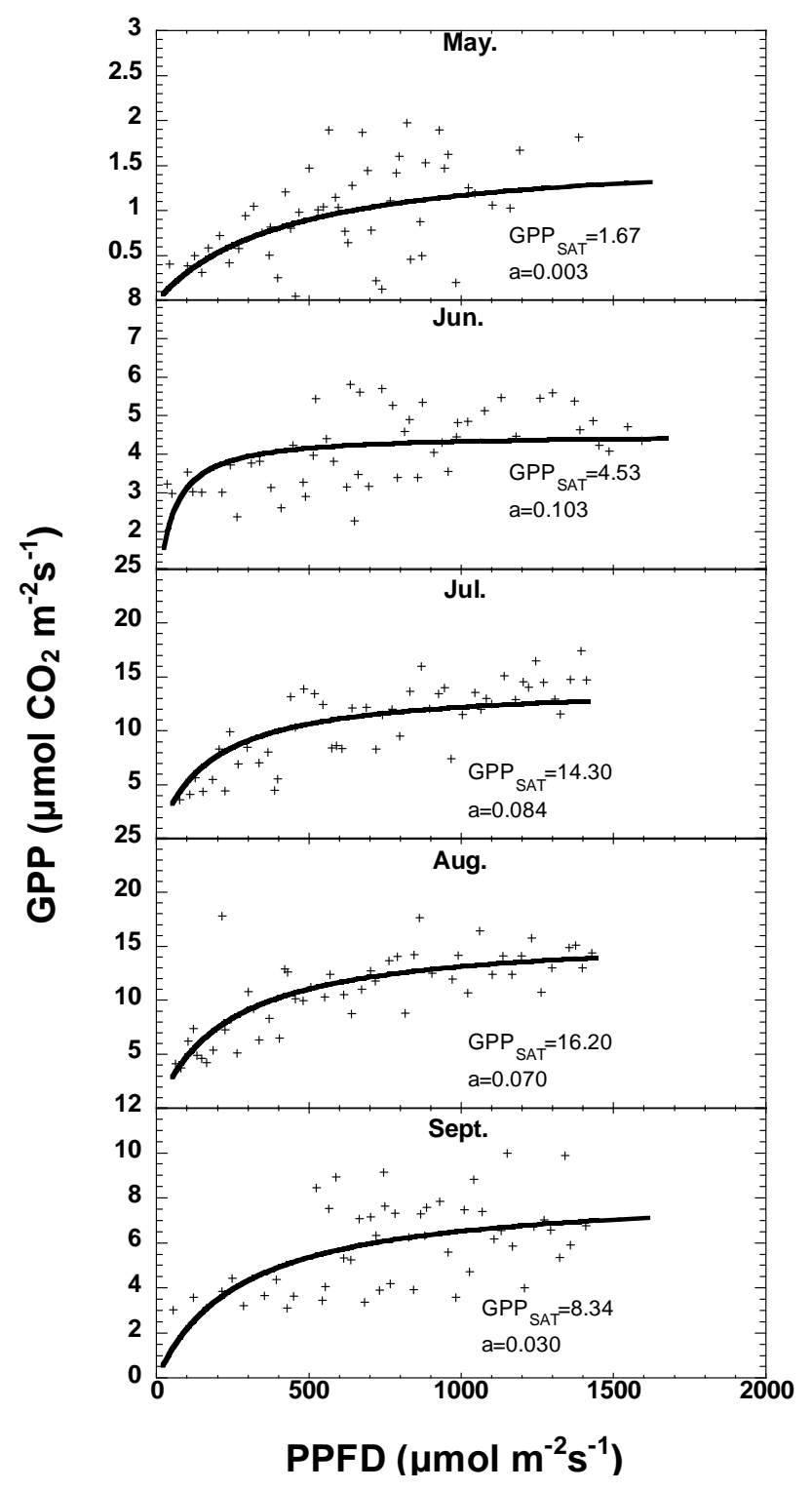

Fig. 4. Relationship between photosynthetic photon flux density (PPFD) and the gross primary production (GPP) from May to September. Fitted curves are exponentially during May to September. Positive values denote $\mathrm{CO}_{2}$ assimilation by the canopy. Data were from 06:00-13:00 (BST). And all of the PPFD were greater than $20 \mu \mathrm{mol} \mathrm{m}^{-2} \mathrm{~s}^{-1}$.

rain event II ( $6.5 \mathrm{~mm}$ rainfall), $R_{\mathrm{eco}}$ again decreased sharply from $8.98 \mathrm{~g} \mathrm{C} \mathrm{m}^{-2}$ per day on October 30 to $4.40 \mathrm{~g} \mathrm{C} \mathrm{m}^{-2}$ per day on 1 November. After the $\mathrm{X}$ rain event $(1.1 \mathrm{~mm})$ on 8 January $2005, R_{\text {eco }}$ decreased from $2.77 \mathrm{~g} \mathrm{C} \mathrm{m}^{-2}$ per day to $1.99 \mathrm{~g} \mathrm{C} \mathrm{m}^{-2}$ per day. After this, $R_{\text {eco }}$ showed an exponential decrease with time (Fig. 7).

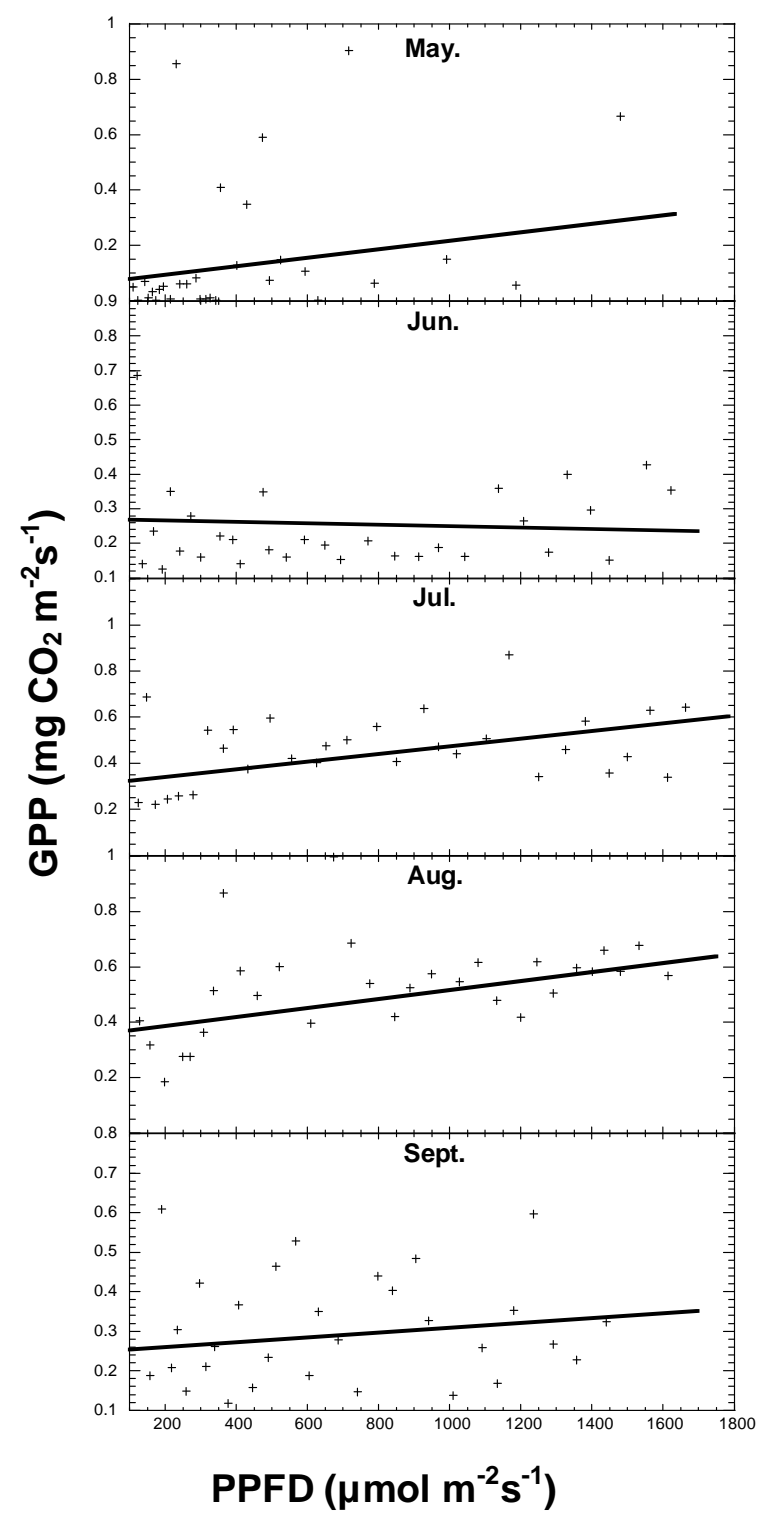

Fig. 5. Linear regression of daytime gross primary production (GPP) on incident photosynthetic photon flux density (PPFD). Data were from 13:00-20:00 (BST). The regression follows a linear relationship: $\mathrm{GPP}=b+a \times \mathrm{PPFD}$. Monthly values are presented as follows: month $\left(a, r^{2}\right)$ - May $\left(0.00015,0.10^{* *}\right)$, June $(-0.00002$, 0.01 n.s.), July $\left(0.00017,0.25^{* *}\right)$, August $\left(0.00016,0.26^{* *}\right)$ and September $\left(0.00006,0.04^{* *}\right)$. The linear relationships were significant at** $P<0.01$ level of correlation coefficients. The term n.s. shows insignificant linear relationships. And all of the PPFD were greater than $100 \mu \mathrm{mol} \mathrm{m}^{-2} \mathrm{~s}^{-1}$.

\subsection{Diurnal variations in NEE}

Seasonal variations in the diurnal patterns of NEE can provide insights into how PPFD and LAI interact to control photosynthesis and respiration. Diurnal sequences of mean NEE and PPFD values at different growth periods are presented 


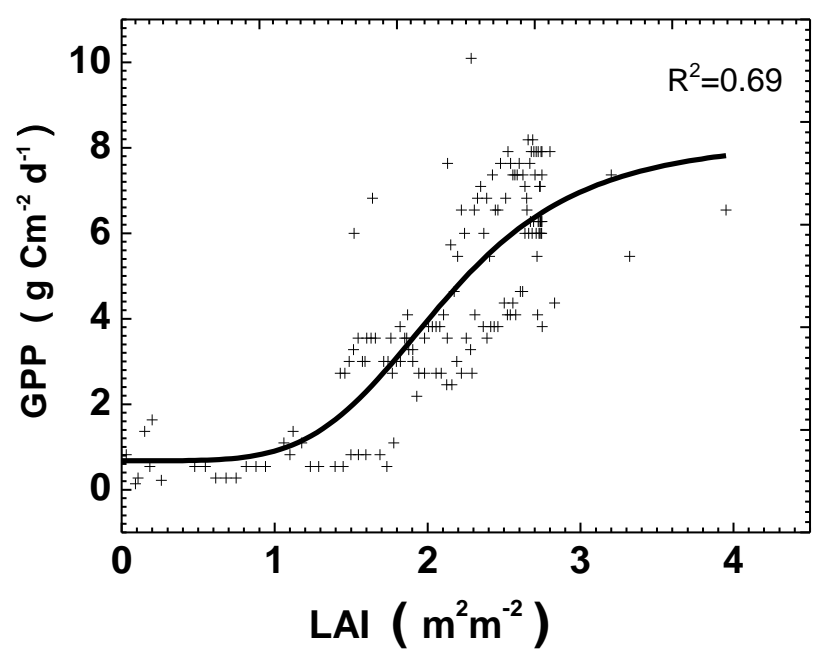

Fig. 6. The relationship of daily total gross primary production (GPP) and leaf area index (LAI). Data were obtained from the growing period in 2005.

in Figs. 8 and 9 try to illustrate this; data from ten consecutive days were combined to reduce the sampling error. Four examples were from sunny days: one from the nongrowing season during DOY 101-110 (before the growing season) and one from DOY 301-310 (the senescent period) in 2005, and the other two from the growing season, DOY 151-160 (with LAI of 2.2) and DOY 206-215 (LAI of 3.2) in 2005. This chart shows that during the non-growing season, diurnal variation of NEE was not obvious or consistent, and was very small at any time (Fig. 8). During the two periods, the releases of $\mathrm{CO}_{2}$ were visibly. Obverse, the differences in amplitude of the diurnal variations in NEE between periods were very small by comparing the release rates of both periods.It can also be noted from Fig. 8 that NEE from 13:00 to 17:00 BST was much higher in the senescent period than that in the pre-growing period, probably due to higher soil temperature. During the growing season, the diurnal variations in NEE showed a similar temporal pattern to the PPFD curves (Fig. 9). The diurnal NEE patterns of daytime uptake and nighttime release are clear. After dawn, NEE moved from a positive value (release) to a negative value (uptake). The highest uptake rate came out around noon and began to decrease afterwards. At dusk, NEE switch a negative value to a positive value. However, positive and negative value changes are also clearly affected by seasonal variations. The highest diurnal uptake rate occur between 11:00-12:00. The maximum net $\mathrm{CO}_{2}$ uptake for the two growing periods, 2.5 and $11.5 \mu \mathrm{mol} \mathrm{m}^{-2} \mathrm{~s}^{-1}$ respectively, indicated that the diurnal variations in NEE depended mainly on LAI. Figure 9 shows that nighttime $R_{\text {eco }}$ was much higher in the peak growth stage (DOY 206-215) than in the early season (DOY 151-160), reflecting the importance of photosynthetic activity to ecosystem respiration

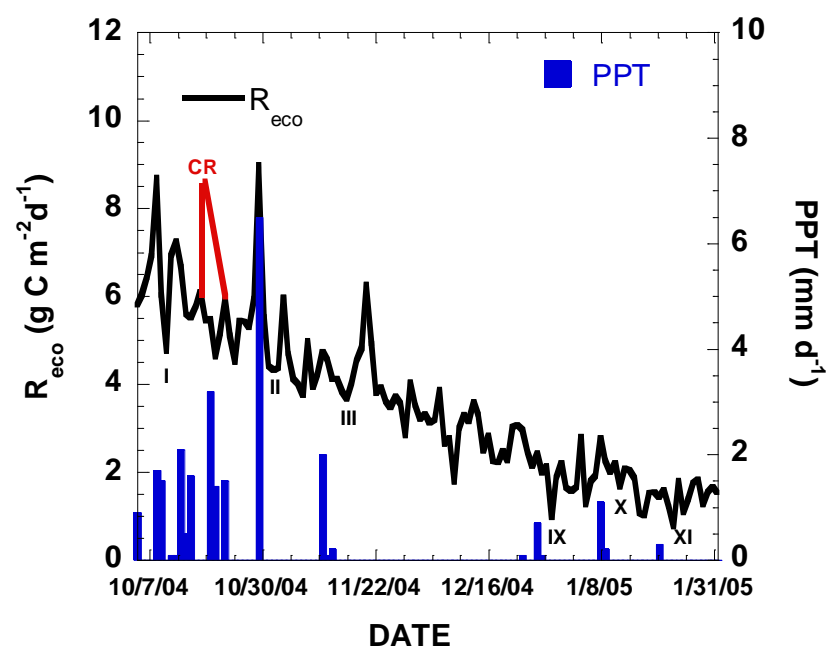

Fig. 7. Examples of influence of rain events on the ecosystem respiration $\left(R_{\text {eco }}\right)$ during 1 October 2004 to 10 February 2005. Data are the daily total $R_{\text {eco }}$ and precipitation (PPT).

(Xu et al., 2004). We compared the observed maximum $\mathrm{CO}_{2}$ uptake with the results of other sites located in similar latitudes. It was slightly larger than alpine $K$. humilis meadow $\left(-10.8 \mu \mathrm{mol} \mathrm{m}{ }^{-2} \mathrm{~s}^{-1}\right.$; Kato et al., 2004a) and alpine shrubland meadow $\left(-10.87 \mu \mathrm{mol} \mathrm{m} \mathrm{m}^{-2} \mathrm{~s}^{-1}\right.$; Zhao et al., 2005) on the same latitudes. The values fell within the range of those reported from other grasslands study sites. For example, Valentini et al. (1995) observed maximum rates of $\mathrm{CO}_{2}$ uptake between -6 and $-8 \mu \mathrm{mol} \mathrm{m} \mathrm{m}^{-2} \mathrm{~s}^{-1}$ in serpentine grassland in California. By contrast, much higher maximum rates of $\mathrm{CO}_{2}$ uptake (between -30 and $-40 \mu \mathrm{mol} \mathrm{m}^{-2} \mathrm{~s}^{-1}$ ) have been reported from more productive perennial grasslands which contain $\mathrm{C}_{4}$ species (Kim and Verma, 1990; Dugas et al., 1999; Suyker and Verma, 2001; Li et al., 2003).

\subsection{Seasonal variations of cumulative GPP, $R_{\text {eco }}$, and NEE}

Figure 10 illustrates the seasonal variations in daily GPP, $R_{\text {eco }}$, and NEE over the course of this study. During the growing season, the three years' data showed similar patterns of seasonal variation in GPP, $R_{\text {eco }}$, and NEE. The seasonal distributions of daily GPP, $R_{\text {eco }}$, and NEE followed the variation of green leaf area for all years. Both GPP and $R_{\text {eco }}$ gradually increased in April and May, and NEE became slightly negative in the end of May. Then as the temperature rose, meanwhile, LAI and day length increased, GPP and $R_{\text {eco }}$ exhibited a rapidly rising trend in June, July, and August, and it would make a strong carbon sink of the ecosystem. The daily maximum net $\mathrm{CO}_{2}$ uptake $\left(-3.9 \mathrm{~g} \mathrm{C} \mathrm{m}^{-2}\right.$ per day), was within the observed range of other alpine meadow ecosystems at similar latitudes $\left(-1.7\right.$ to $-5 \mathrm{~g} \mathrm{C} \mathrm{m}^{-2}$ per day; Kato et al., 2004a; Zhao et al., 2006). The maximum net $\mathrm{CO}_{2}$ uptake observed in this research was 20-55\% less than values 


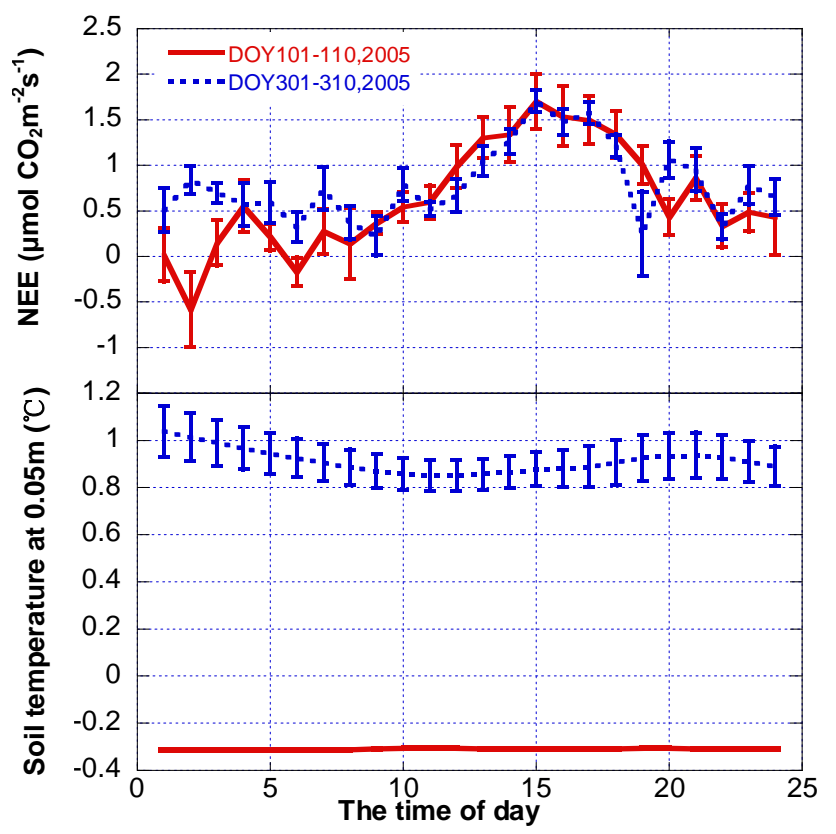

Fig. 8. Examples of 10-day binned diurnal variations in $\mathrm{CO}_{2}$ flux $\left(F_{\mathrm{c}}\right)$ and soil temperature during non- growth periods. (DOY 101110, and DOY 301-310, 2005). Error bars represent the standard deviation.

observed for tallgrass prairies in Kansas, California, and Oklahoma, United States ( -4.8 to $-8.4 \mathrm{~g} \mathrm{C} \mathrm{m}^{-2}$ per day; Kim et al., 1992; Ham and Knapp, 1998; Suyker and Verma, 2001; Xu and Baldocchi, 2004). However, the seasonal maximum observed in this research was almost four times greater than values observed for subalpine conifer forest in Colorado $\left(-1.0 \mathrm{~g} \mathrm{C} \mathrm{m}^{-2}\right.$ per day) at similar altitude $(3050 \mathrm{~m})$. GPP and $R_{\text {eco }}$ plummeted to near-zero about 26 October. After grass senescenced, the grassland continuously lost carbon via soil respiration, but crept along at a very low rate (0.3$0.9 \mathrm{~g} \mathrm{C} \mathrm{m}^{-2}$ per day) due to the low soil temperature.

The authors observed slightly difference about the rates of $R_{\text {eco }}$ varition during the pre-growing period and during the senescence period among the three years. $R_{\text {eco }}$ during the pre-growing period in 2004 and 2006 were $0.72 \mathrm{~g} \mathrm{C} \mathrm{m}^{-2}$ per day and $0.76 \mathrm{~g} \mathrm{C} \mathrm{m}^{-2}$ per day, respectively, compared to $0.58 \mathrm{~g} \mathrm{C} \mathrm{m}^{-2}$ per day in 2005 (Fig. 10). This difference in $R_{\text {eco }}$ values was probably caused by the difference in rain event times in the three years. As shown in Fig. 1, during the pre-growing period in 2005 there were 26 rain events, which caused the ecosystem to lose less carbon than usual. In the senescence period, the observed $R_{\text {eco }}$ were $1.00 \mathrm{~g} \mathrm{~m}^{-2}$ per day in 2004 and $0.95 \mathrm{~g} \mathrm{~m}^{-2}$ per day in 2006 . They were higher than the value of $0.83 \mathrm{~g} \mathrm{~m}^{-2}$ per day in 2005 , it probably caused by the difference in soil temperature.

GPP reached a maximum value $\left(7.15-10.15 \mathrm{~g} \mathrm{C} \mathrm{m}^{-2}\right.$ per day) during mid-August. Information on cumulative carbon exchange (GPP, $R_{\mathrm{eco}}$, and NEE) for the alpine wet-

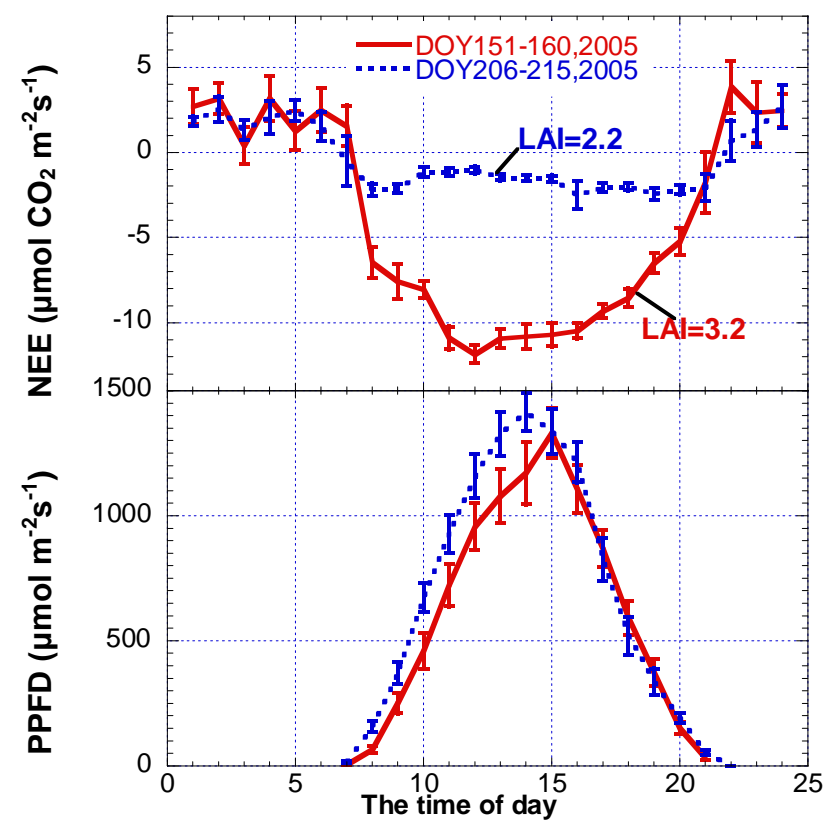

Fig. 9. Examples of 10-day binned diurnal variations in $\mathrm{CO}_{2}$ flux (NEE) and photosynthetic photon flux density (PPFD) during growing periods. (DOY 151-160, and DOY 206-215, 2005.) LAI was around 2.2 and 3.2, respectively. Error bars represent the standard deviation.

land meadow from 1 January 2004 to 31 December 2006, is shown in Fig. 11. Since the growing season for the grass did not extended across two calendar years, cumulative GPP and NEE values were computed over the calendar year. The annual total GPP $\left(R_{\text {eco }}\right)$ were $575.7(676.8) \mathrm{g} \mathrm{C} \mathrm{m}^{-2}$, 682.9(726.4) $\mathrm{g} \mathrm{C} \mathrm{m}^{-2}$, and 631.0(808.2),in 2004, 2005 and 2006, respectively. Thus the NEE were 101.1, 44.0, $173.2 \mathrm{~g} \mathrm{C} \mathrm{m}^{-2}$ correspondingly (Table 1 ). For 2006, the $\mathrm{GPP} / R_{\text {eco }}$ ratio of the ecosystem $(0.78)$ was smaller than for $2004(0.85)$ and $2005(0.86)$. This indicates that the ecosystem released more carbon in 2006 than in 2004 and 2005.

\section{Discussion}

A seasonal variation occurred in NEE. Furthermore, this variation was due to large $\mathrm{CO}_{2}$ fluxes of the release by $R_{\text {eco }}$ and $\mathrm{CO}_{2}$ uptaked by GPP. In general, NEE was slightly positive or almost zero during pre-growing (January-April), and during senescence (October-December). It became negative during June-September, which stands for the end of the growing season or the beginning of the cold season (Fig. 10). This seasonal variation in NEE was driven by opposite patterns of $R_{\text {eco }}$ and GPP. 


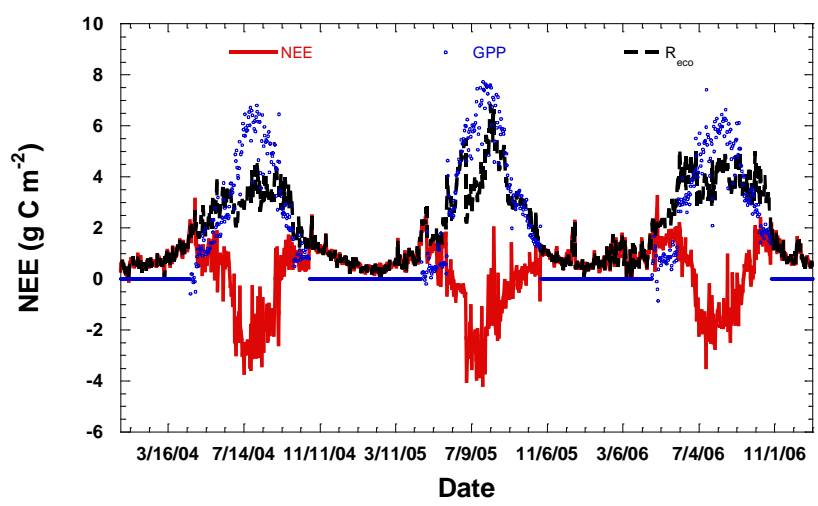

Fig. 10. Seasonal pattern of daily total gross primary production (GPP), net ecosystem exchange (NEE), and ecosystem respiration ( $\left.R_{\text {eco }}\right)$ over the course of the alpine wetland meadow from 1 January 2004 to the end of the year 2006 .

\subsection{Gross primary production (GPP)}

The daily maximum GPP shown a similar pattern to the daily mean GPP. The exponentially relationship between GPP and PPFD (Fig. 4), resulting from that LAI was so small that the rate of canopy photosynthesis was lower than the $\mathrm{CO}_{2}$ emission rate from both plant respiration and soil emission. As the PPFD gradually stabilized, the values of GPP increased from May to August. This result was strongly influenced by the LAI. It increased from 0.09 (7 May) to 3.95 (16 July) and rose with the corresponding leaf-level photosynthetic capacity. However, in September, the dependence of GPP on PPFD did not change greatly as the LAI increased. Because the midsummer air temperature might be higher than the optimum temperature for photosynthesis for some species, especially for $\mathrm{C}_{3}$ plants in this alpine region (Zhao et al., 2005a). Most species flowered and produced seeds before the end of August, whereas NEE decreased under the same conditions of PPFD. This decrease may be due to the reduction in the activity of endemic plants. For higher PPFD, the GPP seemed to approach saturation, a common phenomenon for $\mathrm{C}_{3}$ species. For the fluctuation of GPP, the GPP rate, beforenoon

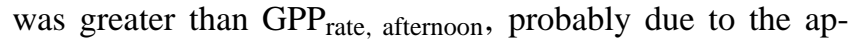
pearance of photo-inhibition. At 13:00, the increased PPFD and temperature induced the stomas closed to avoid wasting much water. Although the PPFD increased, the rate of $\mathrm{CO}_{2}$ became the dominant limiting factor. And the vegetation also experience higher heat load, which enhances respiration, and thus lowers their photosynthesis rates (Chen et al., 2009).

The LAI during the growing season slowly rose in the early growing season (in May) then reached maximum in the peak season (in July), and then slowly decreased, it was corresponding to the trends of the GPP. The LAI ranged from 0 to $0.9 \mathrm{~m}^{2} \mathrm{~m}^{-2}$ mainly occurred within two periods: early spring (May) and late autumn (October). There is a dramatical biological and physical change in the wetland. In

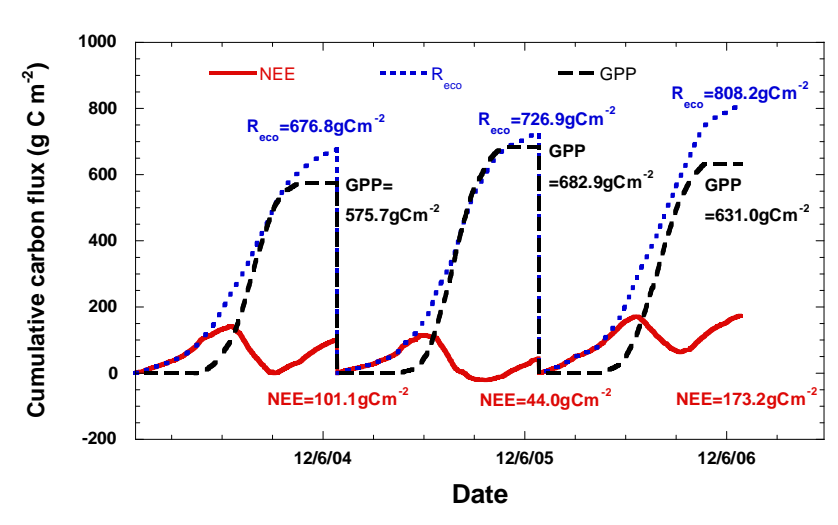

Fig. 11. Cumulative gross primary production (GPP), net ecosystem exchange (NEE), and ecosystem respiration $\left(R_{\mathrm{eco}}\right)$ over the three seasons.

the early spring, the $R_{\text {eco }}$ increased fast with the increase of $T a$ and $T s$. In autumn, leaf senescence, and transpiration of sugars from the above ground to the below ground; it plays a significant role in the high level of $R_{\text {eco. And }}$ the species composition of the wetland ecosystem were nonvascular plants i.e. the relative increase in LAI can produce more dry matter through photosynthesis. On the other hand, the relative coefficients between GPP and $T a, T s$ gradually increased during growing season, and the sensitivities (regression slope) of GPP to $T a$ and $T s$ reached maximum in June $\left(0.334 \mu \mathrm{mol} \mathrm{m} \mathrm{m}^{-2} \mathrm{~d}^{-1}{ }^{\circ} \mathrm{C}^{-1}, 2.025 \mu \mathrm{mol} \mathrm{m}{ }^{-2} \mathrm{~d}^{-1}{ }^{\circ} \mathrm{C}^{-1}\right.$, respectively) (Table 4), indicating that in summer the environment factors especially temperature reaches the optimal for photosynthesis.

For the wetland meadow, over $69 \%$ of the variance in GPP could be explained by changes in LAI. The remaining $31 \%$ of the variance was due to variations in weather, vapor pressure deficit, temperature, and direct and diffuse radiation. The result suggests that LAI determines the ecosystem capacity for assimilation and resource requirements. For example, based on the carbon fluxes data from 18 sites across European forests, Janssens et al. (2001) found that productivity of forests overshadows temperature as a factor determining both soil and ecosystem respiration. A study by Högberg et al. (2001) in a boreal pine forest in Sweden showed that a decrease of up to $37 \%$ in soil respiration was detected within five days after the stem bark of pine trees were girdled. Therefore, when simulating $R_{\text {eco }}$ over the entire season, the impact of canopy photosynthetic activity must be taken into account (Janssens et al., 2001). For the period of peak $\mathrm{CO}_{2}$ uptake, the GPP/LAI values calculated from this meadow ecosystem were $2.8-3.6 \mathrm{~g} \mathrm{C} \mathrm{m}^{-2}$ per day, higher than the values reported in Tappeiner and Cernusca (1996) (1.1-1.5 $\mathrm{g} \mathrm{C} \mathrm{m}^{-2}$ per day), but below the range of other temperate grasslands (Ruimy et al., 1995; Flanagan et al., 2002).

For the daily maximum GPP value $\left(7.15-10.15 \mathrm{~g} \mathrm{C} \mathrm{m}^{-2}\right.$ per day during mid-August), $\mathrm{Xu}$ and Baldocchi (2004) 
reported nearly identical peak daily GPP $\left(10.1 \mathrm{~g} \mathrm{C} \mathrm{m}^{-2}\right.$ per day) in a temperate $\mathrm{C}_{3}$ grassland near Alberta, Canada. But the daily maximum GPP values obtained here were lower than a tallgrass prairie and mid-latitude deciduous forest (19 and $16 \mathrm{~g} \mathrm{C} \mathrm{m}^{-2}$ per day respectively; Turner et al., 2003).

In comparison with the cumulative GPP of similar latitude ecosystems reported by Kato et al. (2006) and Zhao et al. (2006), our observation was close to K. humilis meadow (Kato et al., 2004b, 2006), but larger than the alpine shrubland meadow (Zhao et al., 2006). Although alpine wetland meadow ecosystem has a higher annual GPP than the near area meadow ecosystems, it has an obvious carbon emission, which attributed to the high soil organic matter. The cumulative GPP measured at this site was less than reported values for some grasslands and pastures (Xu and Baldocchi, 2004; Griffis et al., 2003), for temperate deciduous forests (1122$1507 \mathrm{~g} \mathrm{C} \mathrm{m}^{-2}$, Falge et al., 2002), and for most temperate and boreal coniferous forests $\left(992-1570 \mathrm{~g} \mathrm{C} \mathrm{m}^{-2}\right.$, Falge et al., 2002). Thus, although the daily $\mathrm{CO}_{2}$ assimilation of the alpine wetland equal to the California annual grassland ecosystem, it had a lower annual GPP due to the short growing period and lower temperature. Lower values have been reported in Sweden $\left(699 \mathrm{~g} \mathrm{C} \mathrm{m}^{-2}\right.$; Law et al., 2002) and the United States $\left(454 \mathrm{~g} \mathrm{C} \mathrm{m}^{-2}\right.$ by Baldocchi et al., 2000; $407 \mathrm{~g} \mathrm{C} \mathrm{m}^{-2}$ by Zeller and Nikolov, 2000).

\subsection{Ecosystem respiration $\left(R_{\text {eco }}\right)$}

The daily $R_{\text {eco }}$ showed similar seasonal patterns in their seasonal variations. And the daily $R_{\text {eco }}$ were associated more closely with the seasonal pattern of soil temperature than PPFD (Fig. 1). However, $R_{\text {eco }}$ even increased with soil temperature decreased during the same period, according to the variation of $R_{10}$ (Figs. 2, 3). In general, climatic factors control the seasonal changes of respiratory processes stronger than biological factors (Falge et al., 2002). However, $R_{\text {eco }}$ seemed to be tightly associated with aboveground and belowground biomass in alpine meadow (Kato et al., 2004b).

The values of $R_{10}$ during the growing season fell in the range (1.8-6.1) of the numerous observations in wetlands reported in literatures (Svensson, 1980; Chapman and Thurlow, 1996; Silvola et al., 1996). These values of $R_{10}$ were based on seasonal changes in soil temperature, and the dependence on temperature was higher in June than in the other months. The values of $R_{10}(3.4,3.6$, and 3.9 in 2004, 2005, and 2006, respectively) during the growing season were higher than the mean values reported in Kobresia humilis meadow (Kato et al., 2006) and Potentilla fruticosa shrubland (Zhao et al., 2006); it was caused by different vegetation and soil organic matter. These values outside the range (1.33.3) which was reported by Rainch and Schlesinger (1992), but within the range (1.9-5.5) given in other reports for forest (Massman and Lee, 2002). The variation of $R_{10}$ values during the growing season reflected different temperature sensitivities to autotrophic and heterotrophic respiration and the turnover times of the multiple carbon pools. High temperature sensitivity may include the direct physiological effect of temperature on root and microbial activities and the indirect effect related to photosynthetic assimilation and carbon allocation on roots (Davidson et al., 1998). Evidence for the indirect effect of photosynthesis on autotrophic respiration comes from a series of recent studies (Bremer et al., 1998; Bowling et al., 2002; Zhao et al., 2006). In addition, the surface of the frozen soil on the Qinghai-Tibetan Plateau thawed during April to June (Fig. 2), resulting in an increase in $R_{10}$ (Zhao et al., 2006). The annual $R_{10}$ values obtained in this study were higher than alpine meadow (1.60-1.89 $\mu \mathrm{mol} \mathrm{C} \mathrm{m}{ }^{-2} \mathrm{~s}^{-1}$ ) by Kato et al. (2006), and thus manifested that the effects of temperature change on ecosystem respiration in the wetland meadow were larger than the alpine meadow.

The daily maximum values of $R_{\text {eco }}$ were in the range of $4.65-6.79 \mathrm{~g} \mathrm{C} \mathrm{m}^{-2}$ per day. Seasonal maxima of $R_{\text {eco }}$ in a California grassland were approximately $4.0-6.5 \mathrm{~g} \mathrm{C} \mathrm{m}^{-2}$ per day (Flanagan et al., 2002); in a tallgrass prairie, 9$9.5 \mathrm{~g} \mathrm{C} \mathrm{m}^{-2}$ per day (Suyker and Verma, 2001); in a southern boreal forest, $7-12 \mathrm{~g} \mathrm{C} \mathrm{m}^{-2}$ per day (Griffis et al., 2003); and in a tropical peat swamp forest floor, $12 \mathrm{~g} \mathrm{C} \mathrm{m}^{-2}$ per day (Jauhiainen et al., 2005).

With respect to the effect of Depth of Water table ( $\left.D_{\mathrm{WT}}\right)$ on $R_{\text {eco }}$, Nieveen et al. (2005) and Lloyd and Taylor (1994) found no change in soil respiration with water-table location. However, Lloyd (2006) found changes in soil respiration with water-table depth using eddy correlation instrumentation. Silvola et al. (1996) observed an increase of $\mathrm{CO}_{2}$ emissions from peat soil with increases in $D_{\mathrm{WT}}$ along the depths of $0.3-0.4 \mathrm{~m}$. In this study, as $D_{\text {WT }}$ increased, the air-filled porosity also increased, supporting greater aerobic degradation of peat. In the current research, even though $D_{\mathrm{WT}}$ varied little at the field site, the site was still waterlogged. Therefore, oxygen availability in peat would be fairly constant, thus $D_{\mathrm{WT}}$ had little effect on soil respiration. In a similar vein, a few studies have shown that ecosystem respiration is dependent on peat temperature, while not water table level (Bubier et al., 2003; Lafleur et al., 2005). These observations might be explained by the fact that the soil moisture content was relatively invariant in the upper layers, and therefore little change in heterotrophic respiration would be expected to result from observed changes in water-table depth. That is why $D_{\mathrm{WT}}$ was not a limiting factor at this site.

The authors found the evidence that rain events reduced respiration rates, in contrast to others (Zhao et al., 2006). These different conclusions regarding the coupling between $R_{\text {eco }}$ and rain events may explain the different opinion about the effect of soil moisture on $R_{\text {eco }}$. The study site was icebound during the non-growing season, and the soil temperature was relatively steady. Therefore, the authors speculated that oxygen availability in the peat soil was quite stable, and thus rain events had little effect on increasing aerobic degradation. On the other hand, after continuing rain 
events ( $>2 \mathrm{~mm}$ per day), small pulses of increased $R_{\text {eco }}$ (in the range of $0.7-1 \mathrm{~g} \mathrm{C} \mathrm{m}^{-2}$ per day) were observed immediately. Similarly, Zhao et al. (2005c) found that seasonal snowfall influences the ecosystem respiration in a cool wetland on the Qinghai-Tibetan alpine zone. Net ecosystem $\mathrm{CO}_{2}$ exchange under snow-covered conditions was significantly greater than under snow-free conditions.

\subsection{Ecosystem carbon exchange ability}

The alpine wetland meadow was a source of atmospheric $\mathrm{CO}_{2}\left(44.0-173.2 \mathrm{~g} \mathrm{C} \mathrm{m}^{-2}\right)$. Yet Kobresia humilis meadow and alpine shrubland meadow of which climate are similar to our study site were sink (Kato et al., 2006; Zhao et al., 2006) (Table 2).Although the annual GPP of the three ecosystems were comparable, the annual $R_{\mathrm{eco}}$ of the wetland was higher than Kobresia humilis meadow and alpine shrubland meadow $43.5 \%$ and $52.1 \%$, respectively. Both higher soil organic carbon content (wetland: $28.06 \%$; shrubland: $7.54 \%$; Kobresia humilis meadow: 5.19\%, Zhao et al., 2005b) and lower grazing intensity (wetland: 38.8-62.6\%; Kobresia humilis meadow: 82.7-87.1\%) may stimulate ecosystem respiration, and thus lead to a large amount of $\mathrm{C}$ release. The low grazing intensity in a heavily grazed area near our study site increased both aboveground and belowground biomass, and should have an impact on litter decomposition and soil structure, which affect soil respiration.

The extent of carbon release in this alpine wetland meadow ecosystem was similar to other northern ecosystems. The calculated whole-year NEE was similar to other wetland sites and fell within the range of reported data (Table 2). For example, a high-Arctic is located in northern Alaska, Coyne and Kelly (1975) observed a net seasonal uptake of $40 \mathrm{~g} \mathrm{C} \mathrm{m}^{-2} \mathrm{y}^{-1}$, while Suyker et al. (1997) measured a net uptake of $88 \mathrm{~g} \mathrm{C} \mathrm{m}^{-2}$ for a period from mid-May to early October in boreal fen. The most significant carbon loss for wet Arctic ecosystems through $\mathrm{CO}_{2}$ exchange has been reported by Oechel et al. (1997) for both tussock $\left(122 \mathrm{~g} \mathrm{C} \mathrm{m}^{-2} \mathrm{y}^{-1}\right)$ and wet sedge tundras $\left(25.5 \mathrm{~g} \mathrm{C} \mathrm{m}^{-2} \mathrm{y}^{-1}\right)$, and by Oechel et al. (1993), $156 \mathrm{~g} \mathrm{C} \mathrm{m}^{-2} \mathrm{y}^{-1}$ for a tussock tundra and $34 \mathrm{~g} \mathrm{C} \mathrm{m}^{-2} \mathrm{y}^{-1}$ for a wet sedge tundra. However, wet sedge and tussock tundra have also been recorded to be a carbon sink with uptake rates of 27 and $23 \mathrm{~g} \mathrm{C} \mathrm{m}^{-2} \mathrm{y}^{-1}$ by Oechel and Billings (1992), and a sedge-dominated fen at Zackenberg has been observed to be a sink with uptake of $64.4 \mathrm{~g} \mathrm{C} \mathrm{m}^{-2} \mathrm{y}^{-1}$ (Soegaard and Nordstroem, 1999).

The single factor linear regression was preformed between $\mathrm{CO}_{2}$ fluxes and environmental factors (Tables 4 and 5). It is indicated that on the annual base the GPP and $R_{\text {eco }}$ were closely associated with $T a, T s,\left(r^{2}>0.5, P<0.05\right)$. Furthermore, during end of growing season (September to October), $T s$ has greater effect on the GPP. The similar phenomenon was happened at $R_{\text {eco }}$ during the peak of growing stage (June to August). As to NEE, it was also well connected with the both temperatures $(P<0.001)$, but the regress equation is not obvious enough to reach significant level.

To distinguish the factors affecting the seasonal variation in $\mathrm{CO}_{2}$ fluxes among the three years at the alpine wetland ecosystem, a multiple regression analysis was preformed to assess the relationships of GPP, $R_{\text {eco }}$ and NEE with the main environmental factors using daily data on annual base (Table 6). Results show that the variability of GPP, $R_{\text {eco }}$, NEE at the study site significantly connected with changed in air temperature, soil temperature, PPFD, and VPD $(P<0.001)$.

\section{Conclusions}

The conclusions that can be drawn from the current research can be summarized as follows: (i) seasonal trends of GPP and $R_{\text {eco }}$ closely followed the changes of LAI. $R_{\text {eco }}$ followed the exponential variation of soil temperature with seasonallydependent $R_{10}$ values, (ii) carbon dioxide fluxes in an alpine wetland meadow are larger than $K$. humilis meadow and P. fruticosa shrubland meadow which share similar alpine meadow environments and located in cooler seasonal climate areas, (iii) $\mathrm{CO}_{2}$ emissions rates decrease notably after rain events, especially in the non-growing season, and (iv) the alpine wetland meadow was a moderate source of $\mathrm{CO}_{2}$.

Acknowledgements. This work was supported by National Science Foundation of China (Grant No. 30770419, 30500080,), the CAS action-plan for west development (Grant No. KZCX2XB2_06,KSCX2-YW-Z-1020) and National Key Technologies R\&T program (Grant No. 2006BAC01A02).

Edited by: J. Chen

\section{References}

Amthor, J. S., Goulden, M. L., Mungeer, J. W., and Wofsy, S. C.: Testing a mechanistic model of forest-canopy mass and energy exchange using eddy correlation: carbon dioxide and ozone uptake by a mixed oak-maple stand, Aust. J. Plant Physiol.,21, 623651, 1994.

Andreis, H. J.: A water table study on an Everglades peat soil: effects on sugarcane and on soil subsidence. Sugar J., 39, 8-12, 1976.

Aubinet, M., Grelle, A., Ibrom, A., et al.: Estimates of the annual net carbon and water vapor exchange of forests: the EUROFLUX methodology, Adv. Ecol. Res., 30, 113-175, 2000.

Baldocchi, D., Kelliher, F. M., and Black, T. A.: Climate and vegetation controls on boreal zone energy exchange, Glob. Change Biol., 6, 69-83, 2000.

Baldocchi, D., Falge, E., Olson, R., et al.: FLUXNET: a new tool to study the temporal and spatial variability of ecosystem-scale carbon dioxide, water vapor and energy flux densities, B. Am. Meteorol. Soc., 82, 2415-2434, 2001.

Bowling, D. R., McDowell, N., and Bond, B.: ${ }^{13} \mathrm{C}$ content of ecosystem respiration is linked to precipitation and vapor pressure deficit, Oecologia, 131, 113-124, 2002. 
Bremer, D. J., Ham, J., and Owensby, C. E.: Responses of soil respiration to clipping and grazing in a tallgrass prairie, J. Environ. Qual., 27, 1539-1548, 1998.

Bubier, J. L., Bhatia, G., Moore, T. R., Roulet, N. T., and Lafleur, P. M.: Spatial and temporal variability in growing season net ecosystem carbon dioxide exchange at a large peatland in Ontario, Canada. Ecos., 6, 353-367, 2003.

Chapman, S. J. and Thurlow, M.: The influence of climate on $\mathrm{CO}_{2}$ and $\mathrm{CH}_{4}$ emissions from organic soils, Agr. Forest Meteorol., 79, 205-217, 1996.

Chen, B., Black, T. A., Coops, N. C., Krishnana, P., Jassal, R., Brümer, C., and Nesic, Z.: Seasonal controls on interannual variability in carbon dioxide exchange of a near-end-of rotation Douglas-fir stand in the Pacific Northwest, 1997-2006, Glob. Change Biol., 15, 1962-1981, 2009.

Coyne, P. I. and Kelly, J. J.: $\mathrm{CO}_{2}$ exchange in the Alaskan tundra: meteorological assessment by the aerodynamical method, J. Appl. Ecol., 12, 587-611, 1975.

Davidson, E. A., Belk, E., and Boone, R. D.: Soil water content and temperature as independent or confounded factors controlling soil respiration in a temperate mixed hardwood forest, Glob. Change Biol., 4, 217-227, 1998.

Dugas, W. A., Heuer, M. L., and Mayeux, H. S.: Carbon dioxide fluxes over Bermuda grass, native prairie, and sorghum, Agr. Forest Meteorol., 93, 121-139, 1999.

Falge, E., Baldocchi, D. D., and Tenhunen, J.: Seasonality of ecosystem respiration and gross primary production as derived from FLUXNET measurements, Agr. Forest Meteorol., 113, 5374, 2002.

Flanagan, L. B., Wever, L. A., and Carson, P. J.: Seasonal and interannual variation in carbon dioxide exchange and carbon balance in a northern temperate grassland, Glob. Change Biol., 8, 599$615,2002$.

Gu, J., Smith, E. A., and Merritt, J. D.: Remote Sensing of Carbon/Water/Energy Parameters-Testing energy balance closure with GOES-retrieved net radiation and in situ measured eddy correlation fluxes in BOREAS, J. Geophys. Res., 104, 2788127894, 1999.

Gorham, E.: Northern peatlands: role in the carbon cycle and probable responses to climatic warming, Ecol. Appl., 1, 182-195, 1991.

Griffis, T. J., Black, T. A., and Morgenstern, K.: Ecophysiological controls on the carbon balance of three southern boreal forests and southern boreal aspen forest, Agr. Forest Meteorol., 117, 5371, 2003.

Ham, J. M. and Knapp, A. K.: Fluxes of $\mathrm{CO}_{2}$, water vapor, and energy from a prairie ecosystem during the seasonal transition from carbon sink to carbon source, Agr. Forest Meteorol., 89, $1-14,1998$.

Hollinger, D. Y., Kelliher, F. M., Byers, J. N., et al.: Carbon dioxide exchange between an undisturbed old-growth temperate forest and the atmosphere, Ecology, 75, 134-150, 1994.

Hodge, P. W.: Respiration processes in Waikato peat bogs, MSc thesis, University of Waikato, Hamilton, New Zealand, 2002.

Högberg, P., Nordgren, A., Buchmann, N., et al.: Large-scale forest girdling shows that current photosynthesis drives soil respiration, Nature, 411, 789-792, 2001.

Janssens, I. A., Lankreijer, H., Matteucci, G., et al.: Productivity overshadows temperature in determining soil and ecosystem res- piration across European forests, Glob. Change Biol., 7, 269278, 2001.

Jauhiainen, J., Takajashi, H., Heikkinen, J. E. P., et al.: Carbon fluxes from a tropical peat swamp forest floor, Glob. Change Biol., 11, 1788-1797, 2005.

Kato, T., Tang, Y. H., Gu, S., et al.: Carbon dioxide exchange between the atmosphere and an alpine meadow ecosystem on the Qinghai-Tibetan Plateau, China, Agr. Forest Meteorol., 124, 121-134, 2004a.

Kato, T., Tang, Y. H., Gu, S., et al.: Seasonal patterns of gross primary production and ecosystem respiration in an alpine meadow on the Qinghai-Tibetan Plateau, J. Geophys. Res., 109, D12109, doi:10.12109/2003JD003951, 2004b.

Kato, T., Tang, Y., Gu, S., Hirota, M., Du, M. Y., Li, Y. N., and Zhao, X. Q.: Temperature plays a major role in controlling ecosystem $\mathrm{CO}_{2}$ exchange in an alpine meadow on the QinghaiTibetan Plateau, Glob. Change Biol., 12, 1285-1298, 2006.

Kim, J. and Verma, S. B.: Carbon dioxide exchange in a temperate grassland ecosystem, Bound. Lay. Meteorol., 52, 135-149, 1990.

Kim, J., Verma, S. B., and Clement, R. J.: Carbon dioxide budget in temperate grassland ecosystem, J. Geophys. Res., 97, 6057-606, 19923.

Lafleur, P. M., Moore, T. R., Roulet, N. T., and Frolking, S.: Ecosystem respiration in a cool temperate bog depends on peat temperature but not water table, Ecosystem, 8, 619-629, 2005.

Lappalainen, E.: Global Peat Resources, International Peat Society, Finland, 368 pp., 1996.

Law, B. E., Falge, E., Gu, L., et al.: Environmental controls over carbon dioxide and water vapor exchange of terrestrial vegetation, Agr. Forest Meteorol., 113, 97-120, 2002.

Li, S. G., Lai, C. T., Yokoyama, T., and Oikawa, T.: Seasonal variation in energy budget and net ecosystem $\mathrm{CO}_{2}$ exchange over a wet $\mathrm{C}_{3} / \mathrm{C}_{4}$ co-occurring grassland: effects of development of the canopy, Ecol. Res., 18, 661-675, 2003.

Lloyd, J. and Taylor, J. A.: On the temperature dependence of soil respiration, Funct. Ecol., 8, 315-323, 1994.

Lloyd, C. R.: Annual carbon balance of a managed wetland meadow in the Somerset Levels, UK, Agr. Forest Meteorol., 138, 168-179, 2006.

Mahrt, L.: Flux sampling errors for aircraft and towers, J. Atmos. Oceanic Tech., 15, 416-429, 1998.

Matthews, E. and Fung, I.: Methane emission from natural wetlands: global distribution, area, and environmental characteristics of sources, Global Biogeochem. Cy., 1, 61-86, 1987.

Massman, W. J. and Lee, X.: Eddy covariance flux corrections and uncertainties in long-term studies of carbon and energy exchanges, Agr. Forest Meteorol., 113, 121-144, 2002.

Moore, T. R., Roulet, N. T., and Waddington, J. M.: Uncertainty in predicting the effect of climatic change on the carbon cycling of Canadian peatlands, Clim. Change, 40, 229-245, 1998.

Nieveen, J. P., Campbell, D. I., Schipper, L. A., and Blair, I. J.: Carbon exchange of grazed pasture on a drained peat soil, Glob. Change Biol., 11, 607-618, 2005.

Oechel, W. C. and Billings, W. D.: Effects of global change on the carbon balance of Arctic plants and ecosystems, in: Arctic Ecosystems in a Changing Climate: an Ecophysiological Perspective, edited by: Chapin III, F. S., Jefferies, P. L., Reynolds, J. F., Shaver, G. R., and Svoboda, J., Academic Press, London, 139-168, 1992. 
Oechel, W. C., Hastings, S. J., Vourlitis, G., Jenkins, M., Riechers, G., and Grulke, N.: Recent change of Arctic tundra ecosystems from a net carbon dioxide sink to a source, Nature, 361, 520-523, 1993.

Oechel, W. C., Vourlitis, G., and Hastings, S. J.: Cold season $\mathrm{CO}_{2}$ emission from arctic soils, Global Biochem. Cy., 11(2), 163-172, 1997.

Raich, J. W. and Schlesinger, W. H.: The global carbon dioxide flux in soil respiration and its relationship to vegetation and climate, Tellus, 44B, 81-99, 1992.

Ruimy, A., Jarvis, P. G., Baldocchi, D. D., et al.: $\mathrm{CO}_{2}$ fluxes over plant canopies and solar radiation: a review, Adv. Ecolo. Res., 26, 1-68, 1995.

Silvola, J., Alm, J., Ahlholm, U., Nykanen, H., and Martikainen, P. $\mathrm{J} .: \mathrm{CO}_{2}$ fluxes from peat in boreal mires under varying temperature and moisture conditions, J. Ecol., 84, 219-228, 1996.

Soegaard, H. and Nordstroem, C.: Carbon dioxide exchange in a high-arctic fen estimated by eddy covariance measurements and modeling, Glob. Change Biol., 5, 547-562, 1999.

Stephens, J. C., Allen Jr., L. H., and Chen, E.: Organic soil subsidence, in: Man-induced land subsidence, edited by: Holzer, T. L., Geological Society of America Reviews in Engineering Geology, Boulder, CO, USA, Vol. 6, 107-122, 1984.

Sun, H. L. and Zheng, D.: Formation and Evolution of QinghaiXizang Plateau, Shanghai Science and Technology Press, Shanghai, 1996.

Suyker, A. E., Verma, S. B., and Arkebauer, T. J.: Season-long measurements of carbon dioxide exchange in a boreal fen, J. Geophys. Res., 102, 29021-29028, 1997.

Suyker, A. E. and Verma, S. B.: Year-round observations of the net ecosystem exchange of carbon dioxide in a native tallgrass prairie, Glob. Change Biol., 7, 179-289, 2001.

Svensson, B. H.: Carbon dioxide and methane fluxes from the ombrotrophic parts of a subarctic mire, Ecol. Bull. Stockholm, 30, 235-250, 1980.

Tappeiner, U. and Cernusca, A.: Microclimate and fluxes of water vapour, sensible heat and carbon dioxide in structurally differing subalpine plant communities in the Central Caucasus, Plant, Cell and Environ., 19, 403-417, 1996.

Turner, D. P., Urbanski, U., Bremer, D., Wofsy, S. C., Meyers, T., Gower, S. T., and Gregory, M.: A cross-biome comparison of daily light use efficiency for gross primary production, Glob. Change Biol., 9, 383-395, 2003.

Valentini, R., Gamon, J. A., and Field, C. B.: Ecosystem gas exchange in a California grassland: seasonal patterns and implications for scaling, Ecology, 76, 1940-1952, 1995.

Wang, G. X., Qian, J., Cheng, G. D., and Lai, Y. M.: Soil organic carbon pool of grassland soils on the Qinghai-Tibetan Plateau and its global implication, Sci. Total Environ., 291, 207-217, 2002.
Webb, E. K., Pearman, G. I., and Leuning, R.: Correction of flux measurements for density effects due to heat and water vapor transport, Q. J. Roy. Meteorol. Soc., 106, 85-100, 1980.

Wilson, K., Goldstein, A., Falge, E., Aubinet, M., Baldocchi, D., Berbigier, P., Bernhofer, C., Ceulemans, R., Dolman, H., and Field, C.: Energy balance closure at FLUXNET sites, Agr. Forest Meteorol., 113, 223-243, 2002.

$\mathrm{Xu}$, L. and Baldocchi, D. D.: Seasonal variation in carbon dioxide exchange over Mediterranean annual grassland in California, Agr. Forest Meteorol., 123, 79-96, 2004.

$\mathrm{Xu}$, L., Baldocchi, D. D., and Tang, J.: How soil moisture, rain pulses, and growth alter the response of ecosystem respiration to temperature, Global Biol. Geo. Chem. Cy., 18, GB4002, doi:10.1029/2004GB002281, 2004.

Yamamoto, S., Saigusa, N., Harazono, Y., et al.: Present status of AsiaFlux Network and a view toward the future, Extended Abstract, Sixth International Carbon Dioxide Conference, Sendai, Japan, 404-407, 2001.

Zeller, K. F. and Nikolov, N. T.: Quantifying simultaneous fluxes of ozone, carbon dioxide and water vapour above a subalpine forest ecosystem, Environ. Pollut., 107, 1-20, 2000.

Zhao, K.: Marshes and Swamps of China: A Compilation, Science Press of China Beijing, 1999.

Zhao, X. and Zhou, X.: Ecological basis of alpine meadow ecosystem management in Tibet: Haibei Alpine Meadow Ecosystem Research Station, Ambio, 8, 642-647, 1999.

Zhao, L., Li, Y. N., Gu, S., Zhao, X. Q., Xu, S. X., and Yu, G. R.: Carbon dioxide exchange between the atmosphere and an alpine shrubland meadow during the growing season on the QinghaiTibetan plateau, J. Int. Plant Biol., 47, 271-282, 2005 a.

Zhao, L., Li, Y. N., Zhao, X. Q., Xu, S. X., Tang, Y. H., Yu, G. R., Gu, S., Du, M. Y., and Wang, Q. X.: Comparative study of the net exchange of $\mathrm{CO}_{2}$ in 3 types of vegetation ecosystems on the Qinghai-Tibetan Plateau, Chinese Sci. Bull., 50, 1767-1774, 2005 b.

Zhao, L., Xu, S. X., Fu, Y. L., Gu, S., Li, Y. N., Wang, Q. X., Du, M. Y., Zhao, X. Q., and Yu, G. R.: Effects of snow cover on $\mathrm{CO}_{2}$ flux of northern alpine meadow on Qinghai-Tibetan plateau, Acta Agrestia Sinica, 13(3), 242-247, 2005c.

Zhao, L., Li, Y. N., Xu, S. X., Zhou, H. K., Gu, S., Yu, G. R., and Zhao, X. Q.: Diurnal, seasonal and annual variation in net ecosystem $\mathrm{CO}_{2}$ exchange of an alpine shrubland on QinghaiTibetan plateau, Glob. Change Biol., 12, 1940-1953, 2006.

Zhao, L., Xu, S. X., Li, Y. N., Tang, Y. H., Zhao, X. Q., Gu, S., Du, M. Y., and Yu, G. R.: Relations between carbon dioxide fluxes and environmental factors of Kobresia humilis meadows and Potentilla fruticosa meadows, Front. Biol. China 2007, 2(3), $1-9,2007$. 